\title{
Giovana Giacomini
}

\section{A infecção murina pelo Trypanosoma cruzi clone Sylvio X10/4: envolvimento do sistema imune no controle da parasitemia}

Dissertação apresentada ao

Programa de Pós-Graduação em Imunologia do Instituto de Ciências Biomédicas da Universidade de São Paulo, para obtenção do Título de Mestre em Ciências 


\section{Giovana Giacomini}

\section{A infecção murina pelo Trypanosoma cruzi clone Sylvio X10/4: envolvimento do sistema imune no controle da parasitemia}

Dissertação apresentada ao Programa de Pós-Graduação em Imunologia do Instituto de Ciências Biomédicas da Universidade de São Paulo, para obtenção do Título de Mestre em Ciências

Área de concentração: Imunologia

Orientador: Prof. Dr. José Maria Álvarez Mosig

Versão corrigida. A versão original eletrônica encontra-se disponível tanto na Biblioteca do ICB quanto na

Biblioteca Digital de Teses e Dissertações da USP (BDTD).

São Paulo

2012 
DADOS DE CATALOGAÇÃO NA PUBLICAÇÃO (CIP)

Serviço de Biblioteca e Informação Biomédica do

Instituto de Ciências Biomédicas da Universidade de São Paulo

(c) reprodução total

Giacomini, Giovana.

A infecção murina pelo Trypanosoma cruzi clone Sylvio X10/4: envolvimento do sistema imune no controle da parasitemia / Giovana Giacomini. -- São Paulo, 2012.

Orientador: Prof. Dr. José Maria Álvarez Mosig.

Dissertação (Mestrado) - Universidade de São Paulo. Instituto de Ciências Biomédicas. Departamento de Imunologia. Área de concentração: Imunologia. Linha de pesquisa: Imunologia da doença de Chagas.

Versão do título para o inglês: The murine infection by Trypanosoma cruzi clone Sylvio X10/4: immune system involvent in parasitemia control.

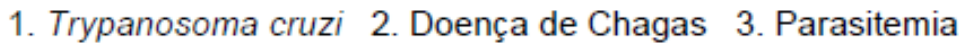
4. Anticorpos 5. INF- $\gamma$ 6. Proteínas de fase aguda I. Mosig, Prof. Dr. José Maria Álvarez II. Universidade de São Paulo. Instituto de Ciências Biomédicas. Programa de Pós-Graduação em Imunologia III. Título. 

envolvimento do sistema imune no controle da parasitemia.

Orientador(a): $\quad$ Prof. Dr. José Maria Álvarez Mosig.

A Comissão Julgadora dos trabalhos de Defesa da Dissertação de Mestrado, em sessão pública realizada a considerou
( ) Aprovado(a)
( ) Reprovado(a)

Examinador(a): Assinatura: Nome:

Instituição:

Examinador(a): Assinatura: Nome:

Instituição:

Presidente: Assinatura:

Nome:

Instituição: 


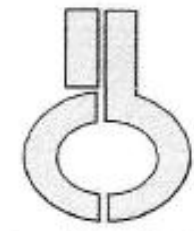

\section{Certificado}

Certificamos que o protocolo registrado sob $n^{\circ} 140$ nas fls. 94 do livro 02 para uso de animais em experimentação, sob a responsabilidade do Prof(a) $\operatorname{Dr}(a)$ José Maria Álvares Mosig, Coordenador(a) da Linha de pesquisa A infecção murina pelo Trypanosoma cruzi clone Sylvio X10/4: Mecanismos envolvidos no controle do parasita e na patologia cardiaca crônica do qual participam o(s) alunos André L.Bombeiro, Christian E. Jorquera-Rosas, Giovana Giacomini, Rafael Moyses Salgado, está de acordo com os Princípios Éticos de Experimentação Animal adotado pela Sociedade Brasileira de Ciência de Animais de Laboratório (SBCAL) e foi aprovado pela COMISSĀO DE ÉTICA NO USO DE ANIMAIS (CEUA) em 23.11.2010, com validade de 3 anos.

São Paulo, 25 de novembro de 2010.

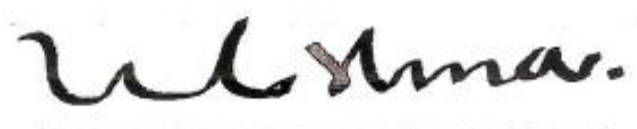

Prof.Dr.WOThan TAVARES DE LIMA

Coordenador CEUA - ICB/USP

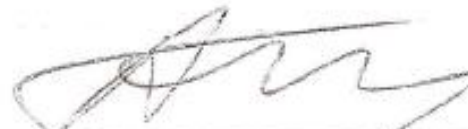

Prof. Dr. ARIEL MARIANO SILBER Secretário-suplente CEUA - ICB/USP 


\section{AGRADECIMENTOS}

Agradeço primeiramente à minha família, pois só com este apoio é que foi possível esta caminhada. Antonio e Selma, obrigada por serem meu porto seguro, pelo amor e carinho dedicado em todos os momentos da minha vida, e por me fazerem ser o que sou. Vanessa, minha irmã querida, obrigada por sempre estar ao meu lado. Tenho um amor muito grande por vocês!

Ao meu namorado Cadu por me apoiar sempre com muito carinho, dedicação e amor em todos esses anos juntos, e por não me deixar desistir frente às dificuldades. E a toda sua família pelo apoio e pelos momentos agradáveis, em especial ao Antonio e à Ismênia que, além de tudo, também colaboraram na finalização desta dissertação.

Agradeço ao meu orientador José Maria Álvarez Mosig (Pepe) pela oportunidade, ensinamentos, paciência e confiança depositada para a realização deste trabalho.

Aos professores colaboradores, Maria Regina D'Império Lima, Denise Vilarinho Tambourgi e Sabrina Epiphanio pelo suporte nos experimentos.

Aos professores da banca de qualificação Maria Notomi Sato, Karina Ramalho Bortoluci e Anderson de Sá Nunes pela contribuição para a finalização deste trabalho.

Agradeço muito aos amigos "chagásicos" Rafael Moysés Salgado, Beatriz Villas Bôas, Christian Jorquera Rosas e Raíssa Fonseca pelo companheirismo, aprendizagem e momentos de descontração. Em especial ao Rafael e à Beatriz que se tornaram amigos muito queridos dentro e fora do laboratório.

Ao Rogério Silva do Nascimento pelo apoio técnico em todos os momentos deste trabalho e pela amizade. 
Aos amigos "maláricos" Érika Salles, Sheyla Castillo, Maria Menezes, Henrique Borges, Genoilson Alves de Brito, Letícia Sarturi e Fernanda Sakurai pelo companheirismo e auxílio. Ao Eduardo Pinheiro do Amaral pela ajuda, conhecimentos transmitidos e proporcionando momentos descontraídos e divertidos ao longo deste período.

À Luana Ortolan, Michelle Sercundes, Daniela Debone e Keitty Pereira pelo apoio, amizade e ensinamentos passados.

Às técnicas Mariane, Jéssica e Áurea pelo suporte.

Finalmente agradeço à Fundação de Amparo à Pesquisa do Estado de São Paulo (FAPESP), à Coordenação de Aperfeiçoamento de Pessoal de Nível Superior (CAPES) e ao Conselho Nacional de Desenvolvimento Científico e Tecnológico (CNPq) pelo suporte financeiro.

Enfim, são gestos de carinho, atenção e delicadeza que nos fazem perceber quanto algumas pessoas são especiais na forma de ser e como são bem-vindas suas ações. Desta forma, agradeço a todos que contribuíram de alguma forma para a realização e conclusão deste trabalho.

Muito obrigada!! 
Este trabalho foi realizado no Laboratório de Imunologia das Parasitoses do Departamento de Imunologia, do Instituto de Ciências Biomédicas, da Universidade de São Paulo, com o auxílio financeiro da FAPESP (Fundação de Amparo à Pesquisa do Estado de São Paulo), projeto número 2010/511450 e bolsa processo número 2010/12324-7 e do CNPq (Conselho Nacional de Desenvolvimento Científico e Tecnológico), bolsa processo número 3032692010-3. 
Aquele que duvida e não pesquisa torna-se não só infeliz, mas também injusto.

(Blaise Pascal)

Viver é a coisa mais rara do mundo. A maioria das pessoas apenas existe.

(Oscar Wilde) 


\section{RESUMO}

GIACOMINI, G. A infecção murina pelo Trypanosoma cruzi clone Sylvio X10/4: envolvimento do sistema imune no controle da parasitemia. 2012. 75 f. Dissertação (Mestrado em Imunologia) - Instituto de Ciências Biomédicas, Universidade de São Paulo, São Paulo, 2012.

O Trypanosoma cruzi, parasita causador da doença de Chagas, exibe ampla heterogeneidade e inclui isolados virulentos e de baixa virulência que somente apresentam parasitemia patente em camundongos imunodeficientes. Poucos estudos analisaram a infecção in vivo com parasitas $T$. cruzi de baixa virulência, apesar de estes poderem representar uma grande parte dos casos em humanos. Aqui nós exploramos o envolvimento do sistema imune nos baixos níveis de parasitemia de camundongos infectados com parasitas de baixa virulência Sylvio X10/4. Camundongos C57BI/6 (WT) inoculados intravenosamente (i.v.) com parasitas Sylvio X10/4 de cultura celular não apresentam parasitemia patente depois de 24 horas e as curvas de saída do sangue destes parasitas são similares àquelas dos parasitas de cultura celular da cepa Y (um isolado de alta virulência). Por outro lado, se os tripomastigotas inoculados foram isolados de camundongos imunodeficientes (SCID ou RAG2KO) infectados, nós observamos que os parasitas Y saem da corrente sanguínea mais lentamente do que os parasitas Sylvio X10/4. A análise da carga parasitária em diferentes órgãos 24 horas após a inoculação i.v. dos parasitas revelou que, apesar do conhecido miotropismo do Sylvio X10/4, a maioria dos parasitas injetados vão para o fígado e baço, assim como na infecção pela cepa $Y$, sugerindo um processo de remoção ativa. $O$ envolvimento dos anticorpos naturais na saída do Sylvio X10/4 foi descartado pela comparação das curvas de parasitemia em camundongos WT ou SCID (que não possuem anticorpos). Uma pequena participação do sistema complemento foi sugerida analisando a parasitemia com Sylvio X10/4 em camundongos WT depletados de C3 pelo tratamento com Cobra Venom Factor (CVF). Nossas observações que camundongos IFN- $\gamma \mathrm{KO}$ infectados com Sylvio X10/4 apresentaram parasitemia intermitente nas primeiras semanas da infecção não podem ser atribuídas à deficiência na produção de proteínas de fase aguda, na medida em que nestes camundongos foram encontrados altos níveis de amiloide $A$ sérica e amiloide $P$ sérica. Enquanto a infecção pelo parasita Sylvio X10/4 progride, anticorpos parasitaespecíficos se tornam cruciais para o controle do parasita, uma vez que camundongos BKO infectados sucumbem à infecção em 2-3 meses. Além disso, um papel protetor foi sugerido para a IgM parasita-específica uma vez que animais CD28KO, que não produzem IgG específica, são mais resistentes à infecção por Sylvio X10/4 do que o BKO; além disso, as proteínas de fase aguda não parecem estar relacionadas às imunodeficiências destes animais. Assim, sugerimos que a rápida saída que segue a inoculação i.v. do Sylvio X10/4 é um processo de remoção ativa. Em longo prazo, não somente a lgG, mas anticorpos parasita-específicos lgM tem um papel importante na proteção. 
Palavras-chave: Trypanosoma cruzi. Doença de Chagas. Parasitemia. Anticorpos. IFN- $\gamma$. Proteínas de fase aguda. 


\begin{abstract}
GIACOMINI, G. The murine infection by Trypanosoma cruzi clone Sylvio X10/4: immune system involvement in parasitemia control. 2012. 75 p. Masters thesis (Immunology) - Instituto de Ciências Biomédicas, Universidade de São Paulo, São Paulo, 2012.

Trypanosoma cruzi, the parasite responsible for Chagas' disease, displays wide heterogeneity and includes virulent isolates and low-virulence ones which only yield patent parasitemias in immunodeficient mice. Few studies analyzed the in vivo infection with low virulence $T$. cruzi parasites in spite these may account for a large portion of human cases. Here we explored the involvement of the immune system in the low level parasitemia of mice infected with low-virulence Sylvio X10/4 parasites. C57BL/6 (WT) mice inoculated intravenously (i.v.) with tissue culture Sylvio X10/4 parasites do not show patent parasitemias after 24 hours and the blood clearance curves of these parasites being similar to those of tissue culture $Y$ strain parasites (a high-virulence isolate). Meanwhile, if the inoculated trypomastigotes were isolated from immunodeficient infected mice (SCID or RAG2KO) we observed that $Y$ parasites leave the bloodstream more slowly than Sylvio X10/4 parasites do. Analysis of parasite loads at different organs 24 hours after i.v. parasite inoculation revealed that, in spite of the known myotropism of Sylvio x10/4, most injected parasites go to the liver and spleen, as well as infection with $Y$ strain, suggesting an active removal process. The involvement of natural antibodies in Sylvio X10/4 removal was discarded by comparing the blood clearance curves in wild-type or SCID mice (which lack antibodies). A small participation of the complement system was suggested by analyzing Sylvio X10/4 parasitemia in WT mice depleted of C3 by cobra venom factor (CVF) treatment. Our observation that Sylvio X10/4-infected IFN- $\gamma \mathrm{KO}$ mice showed intermittent patent parasitemias in the first weeks of infection can not be attributed to deficiency in the production of acute phase proteins, in as much as these mice were found to secrete high levels of serum amyloid $A$ and serum amyloid $P$. As infection by Sylvio X10/4 parasites progressed, parasite-specific antibodies became crucial for parasite control, given that infected BKO mice succumbed to infection in 2-3 months. In addition, a protective role was suggested for parasite-specific IgM since CD28KO mice, which do not produce specific IgG, are more resistant than BKO to infection by Sylvio $\mathrm{X} 10 / 4$; moreover, the acute phase proteins do not appear to be related to immunodeficiency of these animals. Thus, we suggest that the rapid clearance that follows Sylvio X10/4 i.v. inoculation is an active removal process. At the long run, not only IgG, but also IgM parasite-specific antibodies play an important role in protection.
\end{abstract}

Keywords: Trypanosoma cruzi. Chagas' disease. Parasitemia. Antibodies. IFN- $\gamma$. Acute phase proteins. 


\section{LISTA DE ILUSTRAÇÕES}

Figura 1 - Distribuição dos casos de infecção pelo Trypanosoma cruzi .............. 19

Figura 2 - Resposta imune na infecção com Trypanosoma cruzi ....................... 24

Figura 3 - Parasitemias de camundongos inoculados pela via intravenosa com formas tripomastigotas de cultura do clone Sylvio X10/4

Figura 4 - Comparação do perfil da permanência no sangue de parasitas do clone Sylvio X10/4 oriundos de cultura de células que foram mantidos nestas por diferentes tempos

Figura 5 - Parasitemias dos camundongos inoculados pela via intravenosa com formas tripomastigotas de cultura da cepa $Y$ 39

Figura 6 - Parasitemia comparativa clone Sylvio X10/4 …............................. 40

Figura 7 - Parasitemia comparativa cepa $Y$

Figura 8 - Quantificação da carga parasitária por qRT-PCR em diferentes tecidos de animais inoculados pela via intravenosa com parasitas do clone Sylvio X10/4

Figura 9 - Quantificação da carga parasitária por qRT-PCR em diferentes tecidos de animais inoculados pela via intravenosa com parasitas da cepa $Y$.... 44

Figura 10 - Análise comparativa da parasitemia de camundongos WT e SCID inoculados pela via intravenosa com $T$. cruzi do clone Sylvio X10/4 para avaliação do papel dos anticorpos naturais

Figura 11 - Avaliação da depleção de complemento pelo teste de hemólise

Figura 12 - Comparação do perfil da parasitemia em camundongos desprovidos de sistema complemento e camundongos controle que foram inoculados, pela via intravenosa, com parasitas do clone Sylvio X10/4 provenientes de cultura celular.................................................................... 48

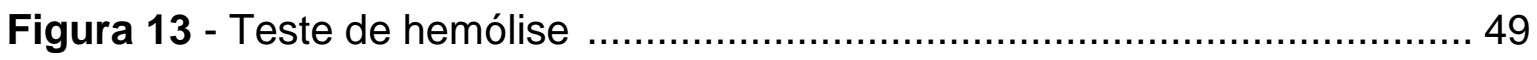

Figura 14 - Comparação do perfil da parasitemia após depleção do sistema complemento

Figura 15 - Parasitemia comparativa de animais WT e IFN- $\gamma \mathrm{KO}$....................... 50

Figura 16 - Sobrevivência de animais WT e IFN- $\gamma$ KO ........................................ 51 
Figura 17 - Quantificação de proteínas de fase aguda em animais WT e IFN$\gamma \mathrm{KO}$

Figura 18 - Sobrevivência de animais WT e BKO 54

Figura 19 - Sobrevivência e parasitemia subpatente de animais WT, BKO e CD28KO infectados pelo $T$. cruzi clone Sylvio X10/4 55

Figura 20 - Quantificação de proteínas de fase aguda em animais WT, BKO e CD28KO 


\section{LISTA DE ABREVIATURAS E SIGLAS}

cDNA - do inglês complementary Deoxyribonucleic Acid (Ácido Desoxirribonucleico complementar)

COBEA - Comissão Brasileira de Experimentação Animal

CRP - do inglês $C$-reactive Protein (Proteína $\mathrm{C}$ reativa)

CVF - do inglês Cobra Venom Factor

DTU - do inglês Discrete Typing Unit

ELISA - do inglês Enzyme-Linked Immunoabsorbent Assay (Ensaio Imunoenzimático)

FIOCRUZ - Fundação Oswaldo Cruz

HRP - do inglês Horseradish Peroxidase

$\lg G$ - Imunoglobulina $G$

$\lg \mathrm{M}$ - Imunoglobulina $\mathrm{M}$

IFN- $\gamma$ - Interferon-gamma

IL - interleucina

i.p. - via intraperitoneal

i.v. - via intravenosa

LIT - do inglês Liver Infusion Tryptose

LLCMK2 - Rhesus Monkey Kidney Cell Line

MAC - do inglês Membrane Attack Complex (Complexo de Ataque à Membrana)

$\mathrm{MBL}$ - do inglês Mannose-Binding Lectin (Lectina Ligante de Manose)

MHC - do inglês Major Histocompatibility Complex (Complexo Principal de Histocompatibilidade)

NK - célula Natural Killer

NLR - do inglês Nod-like Receptor (Receptor do tipo Nod)

$\mathrm{NO}$ - do inglês Nitric Oxide (Óxido Nítrico)

Nod - do inglês Nucleotide-Binding Oligomerization Domain

PBS - do inglês Phosphate Buffered Saline (Salina tamponada com fosfato)

p.i. - pós infecção

PTX3 - do inglês Pentraxin-Related Protein 3 
qRT-PCR - do inglês Real-time reverse transcription polymerase chain reaction (Transcrição reversa da reação em cadeia da polimerase em tempo real)

RAG - do inglês Recombination Activating Gene (Genes Ativadores de Recombinação)

RNA - do inglês Ribonucleic Acid (Ácido Ribonucleico)

RNI - do inglês Reactive Nitrogen Intermediates (Intermediários Reativos de Nitrogênio)

ROI - do inglês Reactive Oxygen Intermediates (Intermediários Reativos de Oxigênio) RPMI - Meio McCoy de cultura modificado rRNA - do inglês ribosomal Ribonucleic Acid (Ácido Ribonucleico ribossomal) SAA - do inglês Serum Amyloid A (Amiloide A sérica)

SAP - do inglês Serum Amyloid P (Amiloide P sérica)

SCID - do inglês Severe Combined Immunodeficiency (Imunodeficiência Combinada Severa)

SFB - Soro Fetal Bovino

T. cruzi - Trypanosoma cruzi

Th - do inglês T helper ( $T$ auxiliar)

TLR - do inglês Toll-like Receptor (Receptor do tipo Toll)

TMB - 3,3',5,5'-tetrametilbenzidina

TNF - do inglês Tumor Necrosis Factor (Fator de Necrose Tumoral)

WHO - do inglês World Health Organization (Organização Mundial da Saúde) WT - do inglês Wild-type (tipo selvagem) 


\section{SUMÁRIO}

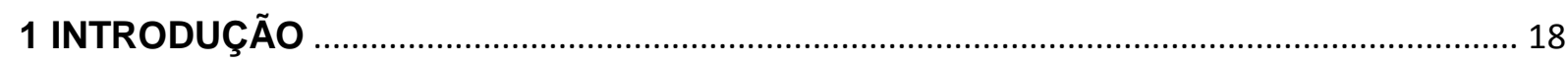

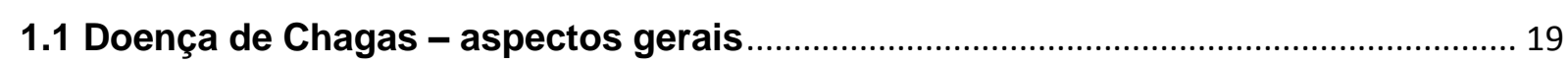

1.2 Manifestações clínicas na doença de Chagas............................................................ 20

1.3 A heterogeneidade do Trypanosoma cruzi.................................................................... 21

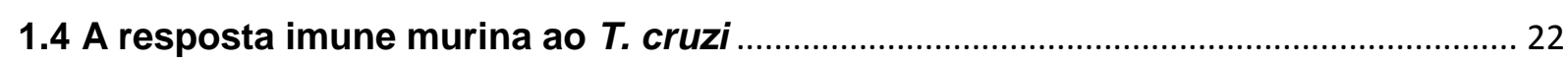

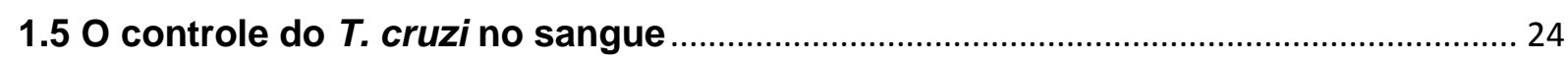

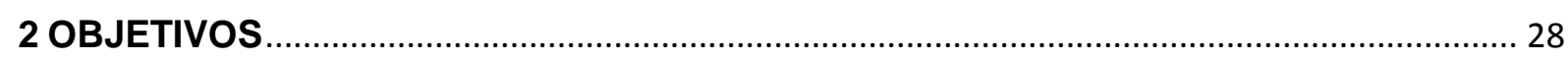

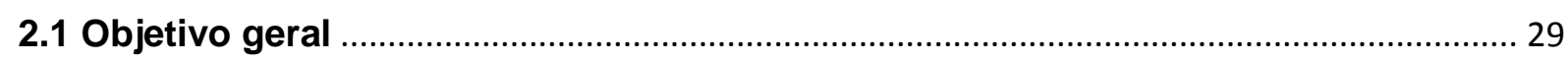

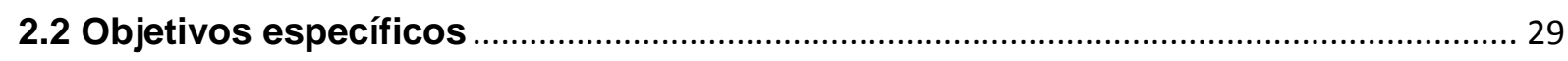

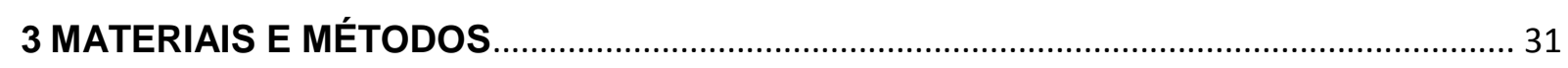

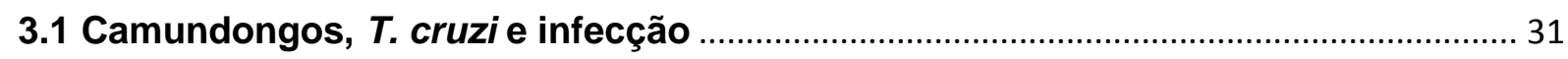

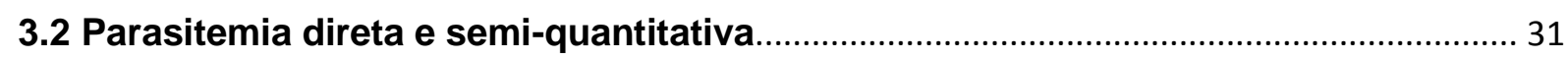

3.3 Avaliação da presença de parasitas vivos em diferentes órgãos ................................. 32

3.4 Expressão gênica específica por meio de qRT-PCR …................................................. 32

3.5 Tratamento com Cobra Venom Factor (CVF) ............................................................ 33

3.6. Quantificação de proteínas no soro dos camundongos.............................................. 33

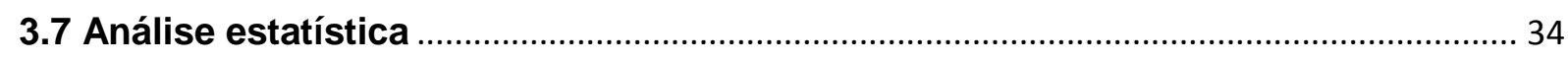

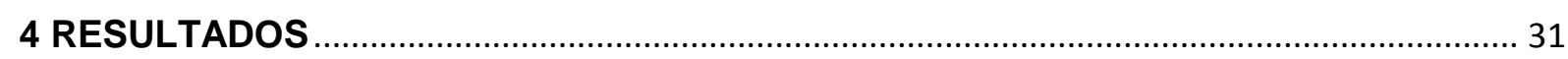

4.1 Saída do Trypanosoma cruzi clone Sylvio X10/4 do sangue após sua inoculação

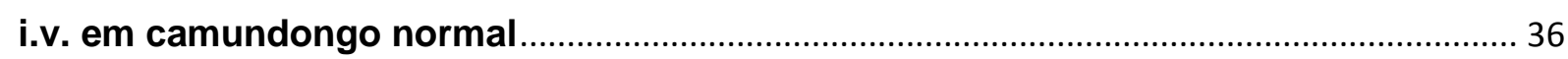

4.2 Avaliação da permanência no sangue de parasitas do clone Sylvio X10/4 provenientes de diferentes dias de cultura após serem inoculados pela via intravenosa

4.3 Análise da parasitemia após inoculação pela via intravenosa de parasitas da cepa Y de Trypanosoma cruzi.

4.4 Estudo comparativo da parasitemia de camundongos inoculados pela via intravenosa com $T$. cruzi clone Sylvio X10/4 ou cepa $Y$ isolados do sangue de animais

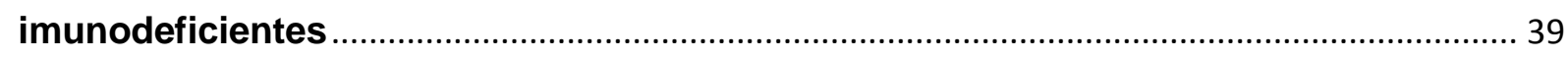

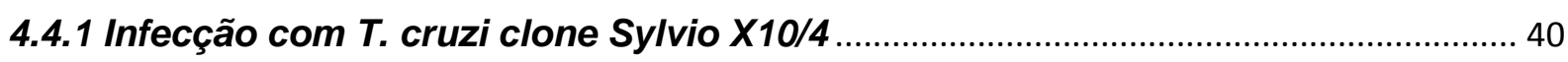

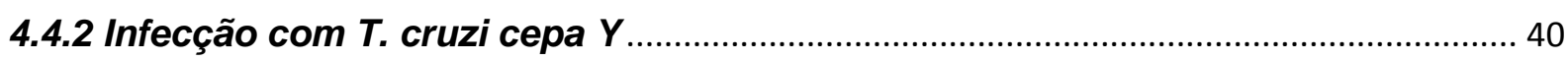

4.5 Análise da carga parasitária em diferentes tecidos .................................................... 41 
4.6 Papel dos anticorpos na saída do parasita do clone Sylvio X10/4 da corrente sanguínea

4.7 Papel do sistema complemento na saída do sangue de parasitas do clone Sylvio $\mathrm{X} 10 / 4$ em animais recém-infectados pela via intravenosa

4.7.1 Papel do sistema complemento na saída do sangue do T. cruzi clone Sylvio X10/4 provenientes de cultura celular

4.7.2 Papel do sistema complemento na saída do sangue do T. cruzi clone Sylvio X10/4 provenientes do sangue de animais imunodeficientes.

4.8 Papel do IFN- $\gamma$ na parasitemia de animais infectados com o clone Sylvio X10/4 .... 49

4.9 Avaliação de proteínas de fase aguda em animais WT e IFN- $\gamma \mathrm{KO}$ infectados com parasitas do clone Sylvio X10/4

4.10 Mortalidade de animais deficientes em linfócitos B e na molécula CD28 infectados com parasitas do clone Sylvio X10/4

4.11 Avaliação de proteínas de fase aguda em animais WT, BKO e CD28KO infectados com parasitas do clone Sylvio X10/4 56

5 DISCUSSÃO. 58

6 CONCLUSÕES 66 
1 INTRODUÇÃO 


\subsection{Doença de Chagas - aspectos gerais}

A doença de Chagas, causada pelo protozoário hemoflagelado Trypanosoma cruzi, foi descrita em 1909 pelo pesquisador brasileiro Carlos Chagas (ANIS; RASSI; MARIN-NETO, 2010). Constitui um problema de saúde pública, uma vez que acomete cerca de 10 milhões de pessoas no mundo (WORLD HEALTH ORGANIZATION, 2012), principalmente na América Latina onde a doença é endêmica (Fig. 1) e resulta em 14.000 mortes a cada ano (HOTEZ et al., 2009).

Figura 1 - Distribuição dos casos de infecção pelo Trypanosoma cruzi

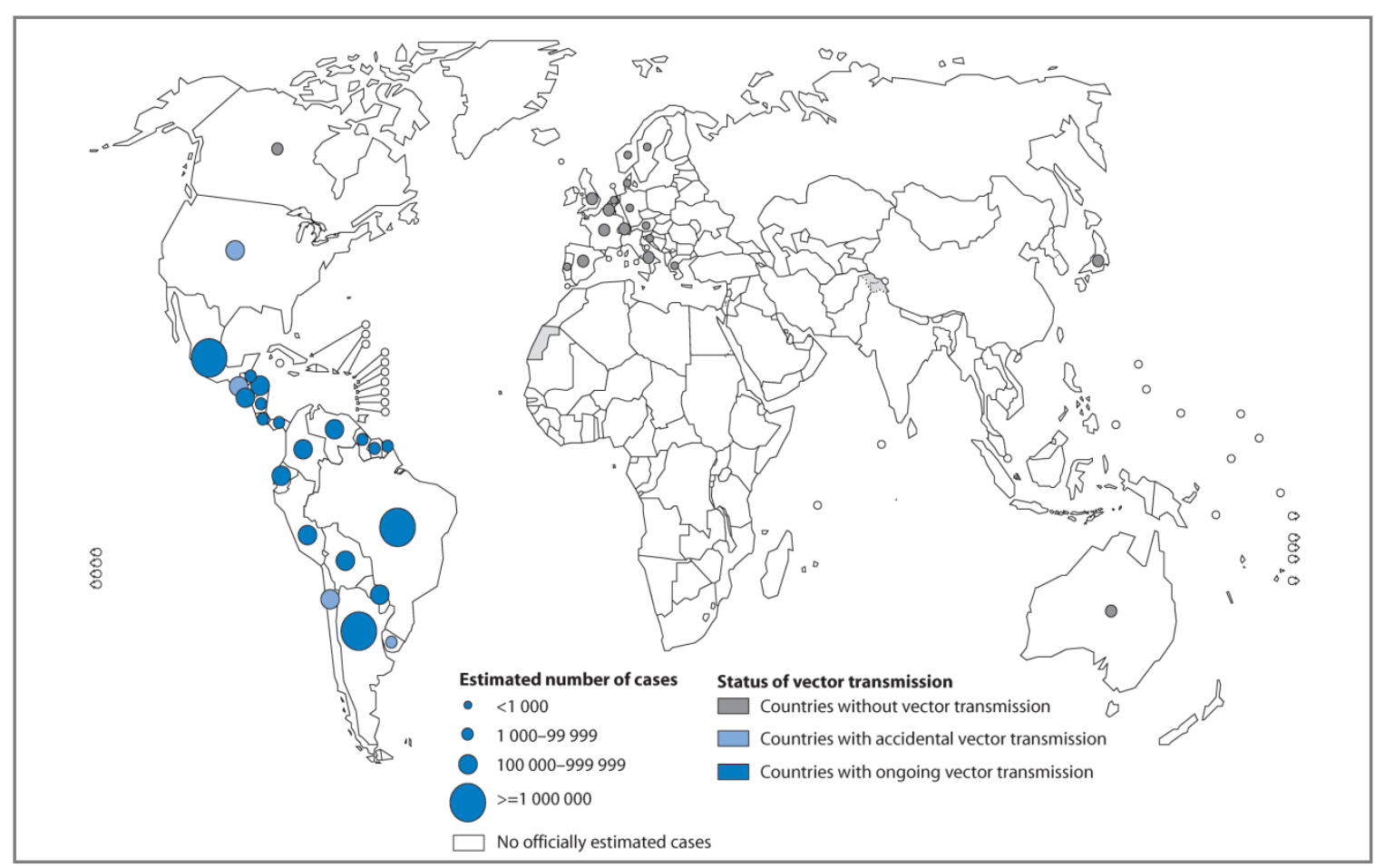

llustração mostrando a distribuição dos casos de infecção pelo $T$. cruzi baseado em estimativas oficiais, e status da transmissão vetorial, no mundo, entre 2006 e 2009.

Fonte: Modificado de (WHO, 2005).

O ciclo doméstico de transmissão do $T$. cruzi inicia-se quando as formas tripomastigotas metacíclicas infectantes presente nas fezes do vetor triatomíneo penetram, através da pele lesada ou mucosa, em diferentes tipos celulares do hospedeiro, se transformando na forma amastigota (JUNQUEIRA et al., 2010). As formas intracelulares amastigotas se multiplicam por fissão binária, se diferenciam em formas tripomastigotas e, após romperem a célula infectada, infectam células adjacentes e caem na corrente sanguínea para então invadir tecidos distantes (BRENER, 1973). A transmissão também pode ocorrer por transfusão sanguínea, via 
transplacentária, via oral, aleitamento materno, acidentes laboratoriais e transplante de órgãos (MACHADO et al., 2009). Políticas de prevenção eficazes à doença de Chagas poderiam envolver o controle eficaz do vetor nas áreas endêmicas; a triagem rigorosa nos bancos de sangue e de possíveis doadores de órgãos e a identificação e tratamento precoce de recém-infectados e de casos ainda na fase assintomática (BIOLO; RIBEIRO; CLAUSSEL, 2010).

A doença de Chagas apresenta três fases clínicas. A fase aguda se caracteriza por parasitemia patente e presença de grande número de ninhos de amastigotas em diversos tecidos; com o estabelecimento de uma resposta imunológica que minimiza a proliferação e disseminação do protozoário, $70-80 \%$ das pessoas infectadas permanece assintomática, característica da fase indeterminada. Por fim, os $20-30 \%$ restantes desenvolvem as formas cardíaca ou digestiva, ou raramente ambas, da fase crônica da doença, com cardiomiopatia e/ou arritmias que podem levar a insuficiência cardíaca congestiva e megassíndromes digestivas do esôfago ou cólon (MARINHO et al., 2004). Contudo, é importante destacar que em um grande número de casos a fase aguda permanece despercebida, seja pela ausência de sintomas ou por estes serem confundidos com os de um quadro febril comum (FUNDAÇÃO OSWALDO CRUZ, 2012).

\subsection{Manifestações clínicas na doença de Chagas}

A cardiomiopatia crônica é a principal manifestação na doença de Chagas com infiltrados de células mononucleares no miocárdio, endocárdio e pericárdio, ninhos de amastigotas e fibrose (MARINHO et al., 2009). Algumas manifestações clínicas envolvem insuficiência cardíaca, arritmias, tromboembolismo, derrame e morte repentina (BIOLO; RIBEIRO; CLAUSELL, 2010). Já a forma digestiva apresenta manifestações como dilatação do trato gastrointestinal e desordens motoras, que se acredita resultem de danos ao sistema nervoso entérico (MATSUDA; MILLER; EVORA, 2009).

Até pouco tempo atrás, a miocardiopatia chagásica era considerada como uma doença parasitária na fase aguda da infecção, com inflamação induzida pela presença do parasita, e como uma doença autoimune na fase crônica (CUNHANETO et al., 1995); no entanto, a miocardiopatia crônica é hoje contemplada como o 
resultado de uma interação multifatorial, persistente e variável entre o parasita e seu hospedeiro (LESCURE et al., 2010). Assim, apesar da escassez de parasitas nas lesões cardíacas (o maior argumento da hipótese autoimune), muitas evidências sugerem que a presença do parasita no coração é que promove o processo de inflamação crônica, com fibrose e perda de células miocárdicas (MARINHO et al., 2009).

\subsection{A heterogeneidade do Trypanosoma cruzi}

O T. cruzi é dotado de uma ampla heterogeneidade. Na Segunda Reunião Satélite da XXXVI Reunião Anual em Pesquisa Básica sobre a Doença de Chagas (Búzios, RJ, agosto de 2009) ficou definido (com base nos conhecimentos atuais) que os isolados de $T$. cruzi podem ser agrupados em 6 conjuntos (DTUs), denominados $T$. cruzi I-VI (ZINGALES et al., 2009). Alguns destes grupos genéticos mostram associação discreta com os ciclos doméstico ou silvestre de transmissão, com a distribuição geográfica do parasita no continente americano e com o desenvolvimento dos diferentes quadros patológicos da doença (BHATTACHARYYA et al., 2010). Ainda em relação à heterogeneidade do parasita, diferentes classificações baseadas na morfologia das formas tripomastigotas, na taxa de mortalidade, na parasitemia induzida na infecção experimental e no tropismo foram descritos. Em relação a este último ponto, as cepas são agrupadas em cepas miotrópicas, que invadem preferencialmente células musculares estriadas, ou reticulotrópicas, que invadem preferencialmente macrófagos (BRENER, 1973).

Devido à dificuldade em trabalhar com a doença em humanos, grande parte da nossa compreensão sobre os fenômenos imunológicos envolvidos na infecção pelo $T$. cruzi foi estabelecida em modelos experimentais murinos. Nestes modelos, os isolados de $T$. cruzi variam desde aqueles que determinam altas parasitemias e levam frequentemente à morte do hospedeiro na fase aguda (MARINHO et al., 1999) até outros que resultam em parasitemias subpatentes (reveladas unicamente por ensaios de amplificação) e promovem baixa ou nenhuma mortalidade em camundongos normais (MARINHO et al., 2007). Ignorando esta heterogeneidade, os estudos de caracterização da resposta imune em camundongos utilizaram, quase que exclusivamente, parasitas de alta virulência. 
O estudo da infecção com parasitas de baixa virulência permite uma visão mais aprofundada, uma vez que possibilita valiosas informações sobre a resposta imune ao $T$. cruzi que passam despercebidas nas infecções por parasitas mais virulentos (MARINHO et al., 2009). No nosso laboratório temos estudado a infecção pelo parasita de baixa virulência Sylvio X10/4, um clone miotrópico de $T$. cruzi tipo I isolado por Miles (MILES, 1974) a partir de parasitas da cepa Sylvio X10 retirados de um inseto Rhodnius prolixus que foi utilizado no xenodiagnóstico de um paciente do Pará com infecção aguda (SILVEIRA et al., 1979). Este T. cruzi promove uma infecção sem parasitemia patente em camundongos normais, e no camundongo $\mathrm{C} 3 \mathrm{H} / \mathrm{HePAS}$ determina um quadro de miocardite crônica que apresenta grandes similaridades com o quadro da miocardiopatia chagásica crônica em humanos (MARINHO et al., 2009).

A diversidade do $T$. cruzi não é, entretanto, o único elemento a ser considerado no desenvolvimento dos diferentes quadros patológicos e evolução da infecção, uma vez que, fatores genéticos do hospedeiro também influenciam na suscetibilidade à infecção (POSTAN, 1987). Além disso, estudos com animais mostraram que há uma relação entre a carga parasitária durante a fase aguda da infecção e a parasitemia, patologia e resposta imune na fase crônica da doença (MARINHO et al., 1999).

\subsection{A resposta imune murina ao $T$. cruzi}

O sistema imune parece estar envolvido nos três principais aspectos da doença de Chagas: i) no controle da replicação do parasita; ii) na sua propagação, e iii) na reação inflamatória nos tecidos infectados (considerada a grande causa de dano tecidual e, consequentemente, de disfunção dos órgãos) (JUNQUEIRA et al., 2010).

Algumas células efetoras do sistema imune, como as células dendríticas, macrófagos e células NK (natural killer), são importantes no controle inicial da replicação do parasita devido à produção de citocinas, como a IL-12 (Interleucina12), TNF- $\alpha$ (Tumor Necrosis Factor- $\alpha$ ) e IFN- $\gamma$ (Interferon- $\gamma$ ), além de moléculas efetoras como intermediários reativos de nitrogênio (Reactive Nitrogen 
Intermediates, RNI) e oxigênio (Reactive Oxygen Intermediates, ROI) (JUNQUEIRA et al., 2010).

As células dendríticas e os macrófagos reconhecem componentes moleculares do $T$. cruzi e orquestram a resposta imunológica. $O$ reconhecimento do parasita se dá por receptores do tipo Toll (Toll-like receptors, TLR), o que determina a produção de citocinas pró-inflamatórias (JUNQUEIRA et al., 2010). Além disso, por se tratar de um parasita intracelular, o reconhecimento do $T$. cruzi também ocorre por membros da família de receptores do tipo Nod (Nod-like receptors, NLR), especialmente Nod1 (Nucleotide-binding oligomerization domain 1), e a cascata que se desenvolve após este reconhecimento culmina com a produção de uma série de citocinas e quimiocinas (SILVA et al., 2010).

Os macrófagos possuem dois papéis distintos na infecção pelo T. cruzi: como célula hospedeira do parasita e como célula efetora na resposta imune. O diferente papel que esta célula vai executar depende do seu estado de ativação no momento da interação com o parasita (GOLDEN; TARLETON, 1991). Ativadas por várias citocinas, principalmente IFN- $\gamma$, a ação citotóxica destas células na erradicação do parasita intracelular se dá principalmente pela ação do óxido nítrico (Nitric Oxide, NO) (KAYAMA; TAKEHARA, 2010) e radicais de oxigênio. Outra população que também possui papel importante na resistência à infecção aguda ao $T$. cruzi é a célula NK, principalmente devido sua produção inicial de IFN- $\gamma$ (ANTÚNEZ; CARDONI, 2000). Estudos apontam que animais ausentes de células NK, ou que as apresentam em menor número, desenvolvem altas parasitemias e altas taxas de mortalidade (ROTTENBERG et al., 1988).

As células dendríticas fazem a ligação da resposta imune inata com a resposta imune adquirida pela apresentação de antígenos do parasita e da produção de IL-12 para a diferenciação de células T helper 1 (Th1) $\mathrm{CD}^{+}$e ativação das células NK (JUNQUEIRA et al., 2010). As células Th1 atuam na infecção pelo seu papel auxiliar na resposta humoral e pela ativação de macrófagos e células T CD8 ${ }^{+}$ citotóxicas por meio da produção de IFN- $\gamma$. Enquanto a citotoxicidade das células $T$ $\mathrm{CD}^{+}$destrói as células contendo amastigotas, os anticorpos produzidos pelos plasmócitos auxiliam na fagocitose das formas tripomastigotas opsonizadas com lgG (JUNQUEIRA et al., 2010) (Fig. 2). 
O IFN- $\gamma$, considerado a molécula chave no controle do $T$. cruzi, está envolvido em vários aspectos da infecção e seu efeito protetor reflete uma combinação de várias atividades efetoras como a indução de óxido nítrico e outras moléculas efetoras dos macrófagos, aumento da expressão de MHC de classe II, polarização Th1 das células $\mathrm{T} \mathrm{CD}^{+}$, mudança de subclasse de anticorpos para lgG2a e produção de quimiocinas (MARINHO et al., 2007).

Figura 2 - Resposta imune na infecção com Trypanosoma cruzi

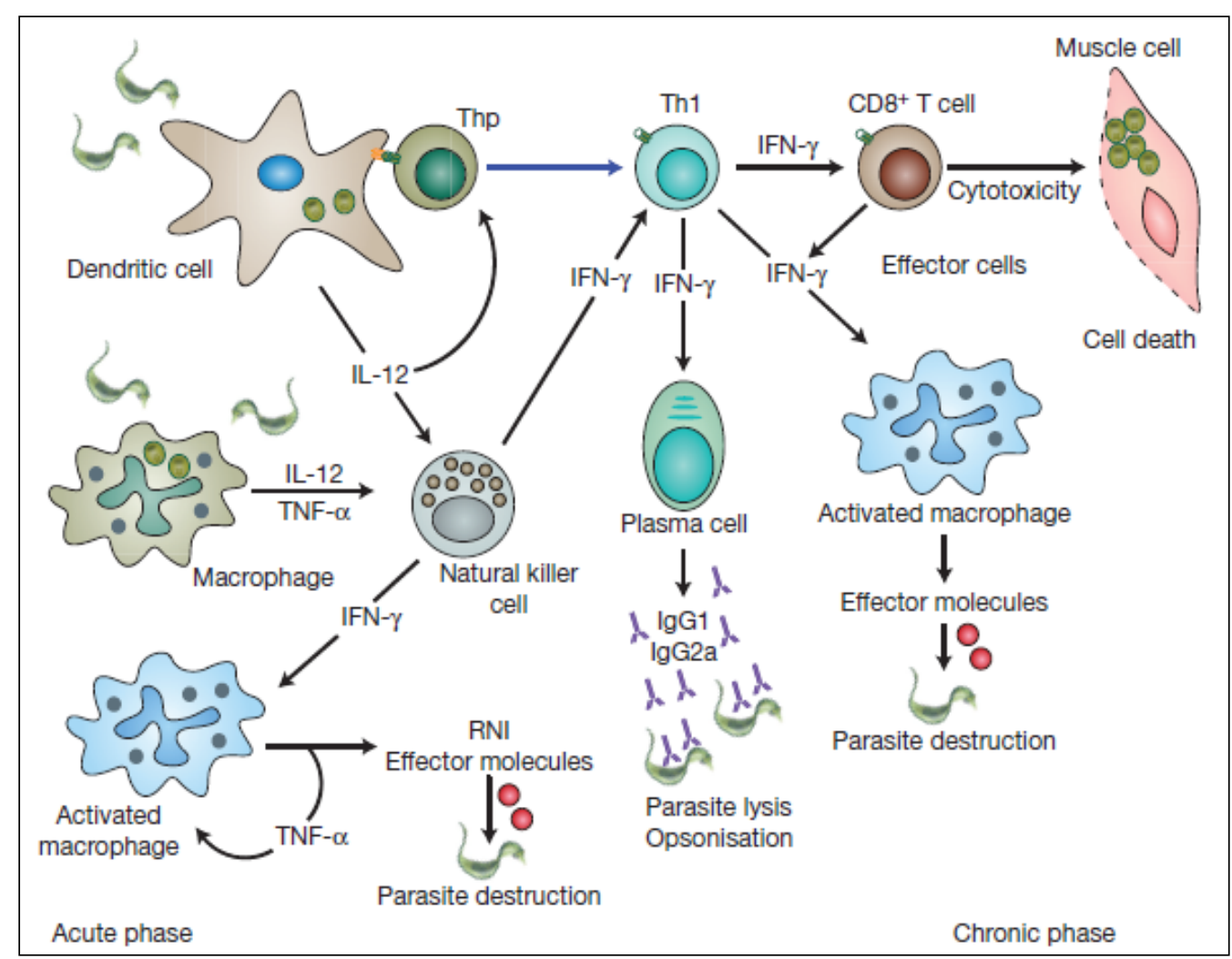

llustração da resposta imune inata e adquirida desencadeada pela infecção pelo $T$. cruzi. Fonte: Junqueira, et al. (2010).

\subsection{0 controle do $T$. cruzi no sangue}

$\mathrm{Na}$ resposta efetora ao Trypanosoma cruzi há o envolvimento de muitas moléculas solúveis (anticorpos, componentes do sistema complemento, citocinas, dentre outras) e diversos tipos celulares, como fagócitos e linfócitos (MARINHO et al., 1999).

Já a partir das primeiras semanas de infecção, os anticorpos específicos das classes IgM e IgG, colaborando com macrófagos e neutrófilos, contribuem para a 
remoção do $T$. cruzi do sangue e do tecido, atuando principalmente pela opsonização do parasita (MARINHO et al., 1999). Os anticorpos parasita-específicos representam uma das mais potentes opsoninas já descritas, promovendo a fagocitose e citotoxicidade nos macrófagos, neutrófilos e células NK (JOSHI; BUTCHAR; TRIDANDAPANI, 2006). Tanto para o clone Sylvio X10/4 como para outras cepas de $T$. cruzi a resposta de anticorpos em camundongos é dominada pelo isotipo IgG2a, em concordância com o perfil predominantemente Th1 da resposta anti-T. cruzi (MARINHO et al., 2009).

O sistema complemento também participa na defesa frente ao T. cruzi. Assim, já foi mostrado que os anticorpos específicos das classes $\lg \mathrm{G}$ e $\lg \mathrm{M}$, produzidos ao longo da infecção contra os epítopos do parasita, ativam o complemento in vitro (pelas vias clássica e alternativa) (KIPNIS et al., 1992). Mais ainda, animais inoculados com CVF (Cobra Venom Factor), que consome o componente C3, apresentam aumento da parasitemia e mortalidade (BUDZKO; PIZZIMENTI; KIERSZENBAUM, 1975). A proteção conferida pelo complemento parece operar em conjunto com os anticorpos específicos da classe lgG, promovendo a opsonização do parasita (UMEKITA; RAMOS; MOTA, 1997). Isto foi demonstrado em animais transferidos com soro de fase crônica, nos quais a remoção das formas tripomastigotas no sangue por células do sistema fagocítico mononuclear foi totalmente abolida após o tratamento com CVF (MOTA; UMEKITA, 1989).

$\mathrm{Na}$ ausência de anticorpos, entretanto, já foi descrito que glicoproteínas na superfície do parasita interferem na formação da C3 convertase da via clássica e alternativa (TAMBOURGI et al., 1995), ou na formação e/ou inserção do complexo de ataque à membrana (Membrane Attack Complex, MAC) (KIPNIS et al., 1992). Contudo, não há informações se o sistema complemento possui algum papel na remoção do T. cruzi no inicio da infecção. Sugestivo desta possibilidade, Cestari e Ramirez (2010) recentemente demonstraram, utilizando soro normal humano não imune, que o sistema complemento pode reconhecer in vitro formas tripomastigotas metacíclicas de diversas linhagens do Trypanosoma cruzi. Estes autores mostraram que a ativação de complemento pelas formas metacíclicas ocorre pela via das lectinas e via alternativa, enquanto a via clássica tem um envolvimento limitado (o que pela sua vez sugere a não participação dos anticorpos naturais no reconhecimento do $T$. cruzi). 
Desconhecemos se outras moléculas solúveis, além dos anticorpos e complemento, participam na remoção do $T$. cruzi no sangue ou tecidos. Em humanos e camundongos, a resposta imune inata a microorganismos abrange uma variedade de respostas celulares e humorais que inclui a produção de proteínas de fase aguda, moléculas sintetizadas pelos hepatócitos após sinalização por citocinas pró-inflamatórias como IL-1, IL-6 e TNF- $\alpha$ (ABBAS; LICHTMAN; PILLAI, 2008; STADNYK; GAULDIE, 1991). Dentre estas, a proteína C reativa (C-Reactive Protein, CRP) e a amiloide $P$ sérica (Serum Amyloid $P$, SAP), sua forma análoga em camundongos, são elementos que participam na remoção de alguns microorganismos, seja por ação opsonizante direta, ou indiretamente por meio da ativação do sistema complemento pela via clássica (STEEL; WHITEHEAD, 1994). Já a ação da amiloide A sérica (Serum Amyloid A, SAA) ainda não está completamente esclarecida, mas algumas funções têm sido descritas e envolvem a modulação da resposta anti e pró-inflamatória (URIELI-SHOVAL; LINKE; MATZNER, 2000). Outra proteína de fase aguda que pode ativar a cascata do complemento, pela via das lectinas, é a lectina ligante de manose (Mannose Binding Lectin, MBL), uma proteína pertencente à família das colectinas que também é sintetizada no fígado, mas que pode ser produzida por macrófagos e outros leucócitos (OGDEN et al., 2001). Mais ainda, já foi descrito o envolvimento da MBL na opsonização de microorganismos e sua ausência relacionada à suscetibilidade a infecções, como sugerido na relação entre a deficiência de MBL e infecção por Pseudomonas em pacientes com fibrose cística (GABOLDE et al., 1999). A MBL se liga a açúcares na superfície dos microorganismos e interage com receptores para colectinas encontrados em vários tipos celulares, incluindo macrófagos (HANSEN et al., 2000). Até o momento não existem dados sobre o envolvimento destas proteínas de fase aguda na infecção pelo $T$. cruzi, assim como da eventual participação destas moléculas na remoção das formas tripomastigotas da corrente sanguínea e dos tecidos.

O entendimento dos mecanismos e/ou elementos envolvidos na saída do $T$. cruzi do sangue requer estudos adicionais. Neste trabalho temos abordado este assunto utilizando o modelo de infecção murina por parasitas Sylvio X10/4, um clone de $T$. cruzi de baixa virulência, escolha que oferece um elemento adicional de interesse. Apesar dos amplos conhecimentos existentes sobre a doença de Chagas, 
desconhecemos qual a frequência de pacientes que apresentam parasitemia manifesta (visível ao microscópio) nas primeiras semanas de infecção e a frequência de pacientes que mostram parasitemia subpatente, ou seja, indetectável pelo exame direto do sangue no microscópio. Enquanto esta característica parece ser dependente do tipo de parasita infectante, desconhecemos a causa subjacente a ausência de parasitemia patente na infecção por diversos isolados. A princípio, duas possibilidades poderiam explicar este fato: a) uma capacidade invasiva exacerbada destes parasitas; e b) uma eficiente remoção dos parasitas do sangue propiciada por algum elemento humoral ou celular do hospedeiro. O estudo desta problemática constitui o objetivo central desta dissertação de mestrado, que foi abordado estudando a parasitemia logo após a inoculação em camundongos, pela via intravenosa, de um número elevado de parasitas Sylvio X10/4, um clone de T. cruzi que, como indicado acima, não induz parasitemia patente em camundongos com sistema imune normal. 


\subsection{Objetivo geral}

O presente estudo tem como objetivo final compreender os vários aspectos e questões relativas à ausência de parasitemia patente na infecção por parasitas do clone Sylvio X10/4.

\subsection{Objetivos específicos}

Analisar a parasitemia e o destino das formas tripomastigotas de T. cruzi do clone Sylvio X10/4 logo após sua inoculação em camundongos pela via intravenosa;

avaliar a importância de algumas moléculas da resposta imune, como anticorpos naturais e sistema complemento, na ausência de parasitemia patente de animais recém-infectados com parasitas do clone Sylvio X10/4, assim como verificar a indução de proteínas de fase aguda no decurso da infecção por estes parasitas;

avaliar a importância da resposta de anticorpos específicos no controle da infecção por parasitas do clone Sylvio X10/4 em fases avançadas da infecção, ou seja, após o desenvolvimento da resposta imune específica ao T. cruzi. 


\subsection{Camundongos, T. cruzi e infecção}

Camundongos fêmea normais da linhagem C57BI/6 WT (Wild-type) e camundongos imunodeficientes SCID, RAG2KO, IFN- $\gamma$ KO, BKO e CD28KO (todos em background $\mathrm{C} 57 \mathrm{~B} \mathrm{I} / 6$ ), com 6 a 8 semanas de idade, foram obtidos do Biotério de Camundongos Isogênicos do Instituto de Ciências Biomédicas da Universidade de São Paulo. Os animais utilizados nos experimentos foram mantidos em estantes ventiladas sob condições controladas de temperatura, umidade e iluminação. Todos os procedimentos que envolvem animais estão de acordo com as diretrizes aprovadas pela Comissão Brasileira de Experimentação Animal (COBEA) e pela Comissão de Ética do Instituto de Ciências Biomédicas da Universidade de São Paulo.

Os animais foram inoculados via intravenosa (i.v.) com formas tripomastigotas do clone Sylvio X10/4 e da cepa $Y$ oriundos de cultura in vitro em células LLCMK2 mantidas em meio RPMI suplementado com 3\% SFB (soro fetal bovino), ou isolados do sangue de camundongos deficientes C57BI/6 SCID ou RAG2KO infectados (que no caso da infecção por parasitas do clone Sylvio X10/4 exibem níveis elevados de parasitemia). Utilizou-se a infecção via intravenosa retrorbital para que os parasitas atinjam a corrente sanguínea de forma imediata, uma necessidade para a rápida avaliação da parasitemia. A infecção dos camundongos foi realizada com $2 \times 10^{5}$ ou $2 \times 10^{6}$ parasitas.

\subsection{Parasitemia direta e semi-quantitativa}

O número de parasitas no sangue circulante foi determinado nos tempos de 10, 30, 60 minutos e 24 horas após a infecção de acordo com o método previamente descrito por Melo e Brener (1978). Assim, $5 \mu \mathrm{l}$ de sangue da cauda dos animais infectados foram colhidos, colocados sobre uma lâmina e coberta por uma lamínula para obter uma camada que ocupe homogeneamente toda a superfície da lamínula. Esta lâmina foi levada ao microscópio óptico (400X) e o número de formas tripomastigotas determinados em 50 campos. Desta forma, conhecendo-se a área de cada campo microscópico, foi possível determinar a quantidade de parasitas por $\mathrm{mL}$. 
Além deste procedimento, também foi feita a análise semi-quantitativa da parasitemia subpatente por cultura em meio LIT (Liver Infusion Tryptose) de alíquotas de $1 \mu \mathrm{l}$ e $5 \mu \mathrm{l}$ de sangue, em quintuplicatas. As culturas foram mantidas a $28{ }^{\circ} \mathrm{C}$ e a cada 7 dias observadas para verificar a presença de parasitas, num período total de 21 dias.

\subsection{Avaliação da presença de parasitas vivos em diferentes órgãos}

A avaliação da presença de parasitas vivos foi realizada por cultura em meio LIT, com alíquotas contendo 0,1 e $0,5 \mathrm{mg}$ de tecido homogeneizado, em quintuplicatas, dos seguintes órgãos: coração, pulmão, fígado, baço, estômago, intestino, gordura e músculo estriado esquelético. Para evitar a contaminação dos órgãos com sangue periférico, os animais foram perfundidos com a veia cava inferior seccionada e salina tamponada com fosfato (Phosphate Buffered Saline, PBS) injetada por uma bomba peristáltica Pump Pro TPM (Watson-Marlow Inc., Wilmington, Massachusetts, USA) no ventrículo direito. A análise das culturas em meio LIT se dá avaliando o número de culturas que positivaram e o número de animais positivos.

\subsection{Expressão gênica específica por meio de qRT-PCR}

Para realização dos ensaios de qRT-PCR, coração, pulmão, fígado, baço, estômago, intestino, gordura e músculo estriado esquelético dos camundongos previamente perfundidos foram congelados em nitrogênio líquido, macerados e armazenados em Trizol ${ }^{\circledR}$ (Invitrogen Life Technologies, Carlsbad, California, USA) a -

$80{ }^{\circ} \mathrm{C}$ até a data de processamento. O RNA total foi obtido utilizando o Kit RNeasy ${ }^{\circledR}$ Mini (Qiagen, Germantown, Maryland, USA) seguindo o protocolo do fabricante para tecidos animais. Um micrograma de RNA total foi convertido em cDNA (High Capacity cDNA Reverse Transcription Kit, Applied Biosystems Life Technologies, Carlsbad, California, USA) de acordo com as especificações do fabricante. A expressão foi quantificada por qRT-PCR utilizando-se o ensaio Platinum ${ }^{\circledR}$ SYBR $^{\circledR}$ Green (Invitrogen Life Technologies) e 4pmol/ $\mu$ l de primers específicos para o gene 18S rRNA (AF303659) - Tc18S-F 5'- TTGAATTGAGGGCCTCTAAGG-3' e Tc18S-R 
5'- AAAGGTACCACTCCCGTGTTT-3' (SARDINHA et al., 2010). A quantificação dos genes selecionados foi avaliada usando o equipamento e software $A B I 7500$ Fast Real-Time PCR System (Applied Biosystems) e levaram em consideração valores da curva padrão com concentração entre $2,5 \times 10^{1}$ a $2,5 \times 10^{7}$ cópias de cDNA de $T$. cruzi.

\subsection{Tratamento com Cobra Venom Factor (CVF)}

Camundongos fêmea normais da linhagem C57BI/6 WT receberam, via intraperitoneal (i.p.), duas doses de $13 \mu \mathrm{g}$ de Cobra Venom Factor de Naja naja em um intervalo de 24 horas. Os animais controle foram inoculados com PBS nas mesmas condições dos camundongos tratados com CVF. A inoculação das formas tripomastigotas do clone Sylvio X10/4 ocorreu, aproximadamente, 3 horas após a última dose do tratamento.

A análise da ação do CVF sobre o sistema complemento foi realizada por meio de um ensaio hemolítico. Sumariamente, eritrócitos de coelhos (EC) foram sensibilizados com anticorpos de camundongo anti-EC. Posteriormente, estes eritrócitos foram incubados com soro dos animais tratados com CVF ou PBS e a atividade hemolítica avaliada por meio da liberação de hemoglobina.

Da mesma forma que o tratamento dos animais, a avaliação da atividade hemolítica do soro destes animais foi realizada em colaboração com a Profa. Dra. Denise Vilarinho Tambourgi (Laboratório de Imunoquímica, Divisão de Desenvolvimento Científico, Instituto Butantan).

\subsection{Quantificação de proteínas no soro dos camundongos}

Foram utilizados kits de ELISA (Enzyme-Linked Immunoabsorbent Assay) para avaliação de quatro proteínas de fase aguda: CRP, SAA, SAP e MBL. Para as três primeiras, às placas de 96 poços pré-sensibilizadas e bloqueadas (ICL Inc., Portland, Oregon, USA) foram acrescentados $100 \mu \mathrm{l}$ das amostras de soro, diluídas de acordo com as instruções do fabricante, obtidas de camundongos C57BI/6 WT, IFN- $\gamma \mathrm{KO}, \mathrm{BKO}$ e CD28KO não infectados ou infectados por parasitas do clone Sylvio $\mathrm{X} 10 / 4$, e incubadas por 1 hora a temperatura ambiente, seguido de 4 lavagens com Wash Solution. As reações foram reveladas incubando por 60 minutos com Enzyme- 
Antibody Conjugate HRP específicos para CRP, SAA e SAP de camundongo, seguido de incubação com $100 \mu$ l/poço de TMB. Após 10 minutos, a reação foi bloqueada com $100 \mu \mathrm{l} /$ poço de Stop Solution e os valores de absorbância (450 nm) lidos em um leitor Epoch (BioTek Instruments Inc., Winooski, Vermont, USA).

Para a quantificação da proteína MBL foi utilizado um kit de ELISA (USCN Inc., Houston, Texas, USA) na qual à placa de 96 poços pré-sensibilizada e bloqueada foi acrescentado $100 \mu \mathrm{l}$ das amostras de soro, diluídas de acordo com as instruções do fabricante, obtidas de camundongos C57BI/6 WT, IFN- $\gamma \mathrm{KO}$, BKO e CD28KO não infectados ou infectados por parasitas do clone Sylvio X10/4, e incubadas por 2 horas a $37^{\circ} \mathrm{C}$. Posteriormente, foram adicionados $100 \mu \mathrm{l} /$ poço do Detection Reagent $A$ seguido de uma incubação de 1 hora a $37^{\circ} \mathrm{C}$. A seguir foram feitas 3 lavagens com Wash Solution e acrescentado $100 \mu \mathrm{l} /$ poço do Detection Reagent $B$. Após 5 lavagens as reações foram reveladas incubando com $90 \mu \mathrm{l} /$ poço de Substrate Solution protegidas da luz. Após 10-15 minutos, a reação foi bloqueada com $50 \mu$ l/poço de Stop Solution e os valores de absorbância (450 nm), assim como nos outros ensaios, lidos em um leitor Epoch.

\subsection{Análise estatística}

Para as análises comparativas entre os grupos experimentais adotamos o teste Two-way ANOVA, seguido do Teste de Bonferroni, e o teste Log-rank (MantelCox), feitos no programa Prisma 5 (Graph Pad Software, La Jolla, California, USA), aplicados de acordo com cada situação como descrito nas legendas das figuras. Para saber se os grupos são significativamente diferentes ou se os resultados obtidos são frutos de mera flutuação randômica ou acaso, as diferenças entre as amostras foram expressas com média \pm desvio padrão da amostra (Média $\pm S D$ ). Diferenças entre os grupos foram consideradas significativas quando $p<0,05$. 
Considerando que a resposta imune ao Trypanosoma cruzi envolve vários elementos na tentativa de suprimir a replicação e a propagação do parasita para os tecidos do hospedeiro, buscamos apresentar separadamente em nossos resultados os diferentes aspectos avaliados.

\subsection{Saída do Trypanosoma cruzi clone Sylvio X10/4 do sangue após sua inoculação i.v. em camundongo normal}

Com o intuito de verificar a saída do parasita do sangue foi analisada a parasitemia em diferentes tempos (10, 30, 60 minutos e 24 horas), logo após a inoculação, via intravenosa, de animais C57BI/6 WT com $2 \times 10^{6}$ formas tripomastigotas procedentes de cultura de células (dia 9 de cultura). Como esperado, foi observado queda no número de parasitas no sangue, sendo que às 24 horas, último tempo avaliado, eles não puderam mais ser encontrados (Fig. 3A). No entanto, apesar da parasitemia não ser detectada pelo exame de amostras de sangue fresco após 24 horas de infecção, ela foi demonstrada por hemocultura (POSTAN; DVORAK; McDANIEL, 1983). Assim, a parasitemia subpatente aos 8 dias da infecção foi confirmada por hemocultura em meio LIT, observando-se resultados semelhantes quando alíquotas de $5 \mu \mathrm{L}$ e $1 \mu \mathrm{L}$ de sangue foram avaliadas (Fig. 3B). 
Figura 3 - Parasitemias de camundongos inoculados pela via intravenosa com formas tripomastigotas de cultura do clone Sylvio X10/4
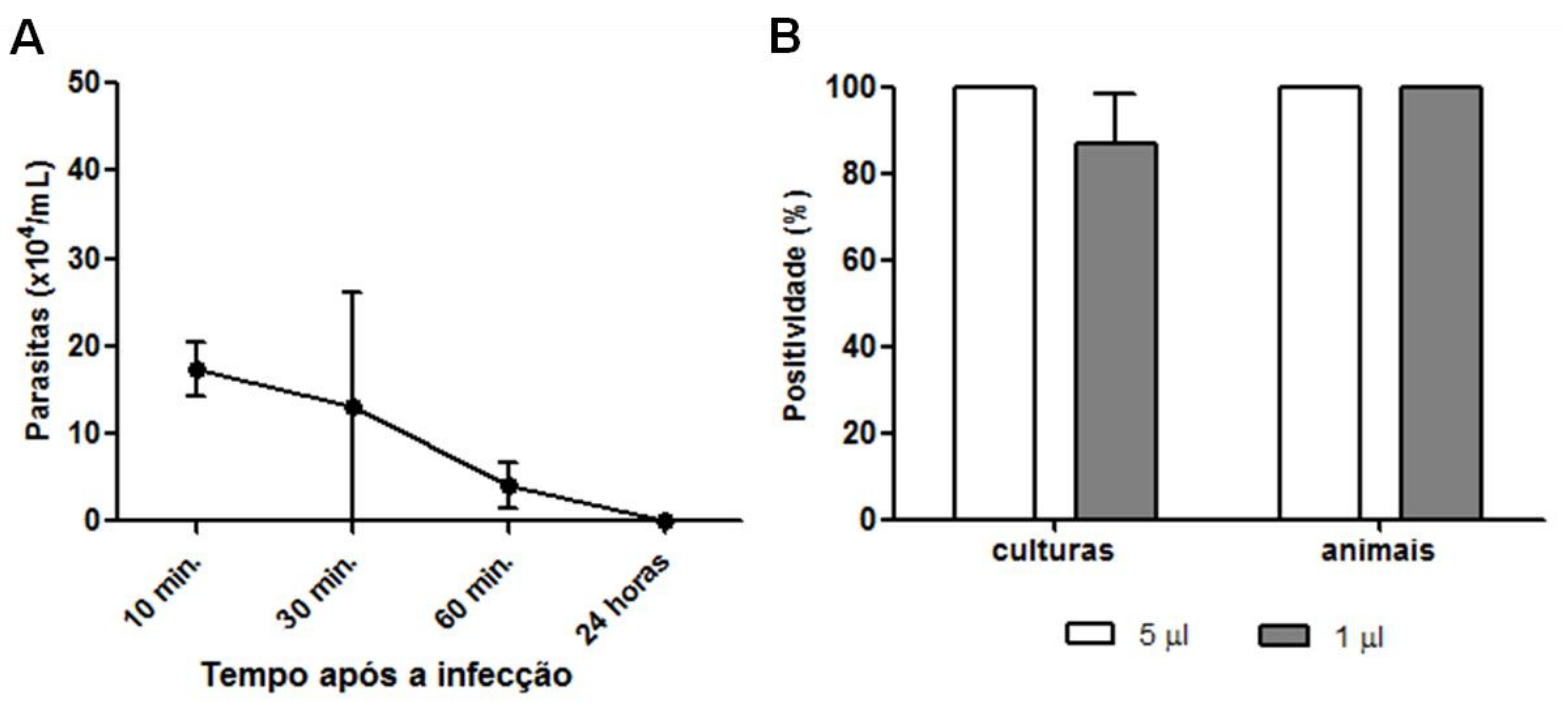

Camundongos C57BI/6 WT foram infectados i.v. com $2 \times 10^{6}$ formas tripomastigotas de cultura do clone Sylvio X10/4. (A) Curva de parasitemia patente. (B) Parasitemia subpatente (hemocultura em meio LIT com alíquotas de $5 \mu \mathrm{l} \mathrm{e} 1 \mu \mathrm{l}$ em quintuplicata do sangue de cada camundongo aos 8 dias de infecção). Dados expressos como Média $\pm S D$ de um experimento com 3 animais.

\subsection{Avaliação da permanência no sangue de parasitas do clone Sylvio X10/4 provenientes de diferentes dias de cultura após serem inoculados pela via intravenosa}

No intuito de avaliar possíveis diferenças na saída do sangue dos parasitas do clone Sylvio X10/4 que foram mantidos em cultura celular por diferentes tempos, foram infectados camundongos C57BI/ $6 \mathrm{WT}$, via intravenosa, com $2 \times 10^{6}$ parasitas obtidos nos dias 7 ou 9 de cultura, e observamos que aos 10 minutos de inoculação há uma quantidade significativamente maior de formas tripomastigotas circulantes no sangue nos animais injetados com parasitas do $7^{0}$ dia de cultura (Fig. 4A). Como complemento desta experiência, após 14 dias da infecção foi analisada a parasitemia subpatente dos animais inoculados com parasitas de dias 7 ou 9 de cultura, não se observando diferenças significativas, tanto na análise da frequência de culturas LIT positivas, quanto na frequência dos animais que geraram culturas positivas (Fig. 4B). Assim, devido os resultados obtidos adotamos os parasitas de $7^{\circ}$ dia de cultura para os demais experimentos de infecção. 
Figura 4 - Comparação do perfil da permanência no sangue de parasitas do clone Sylvio X10/4 oriundos de cultura de células que foram mantidos nestas por diferentes tempos

A

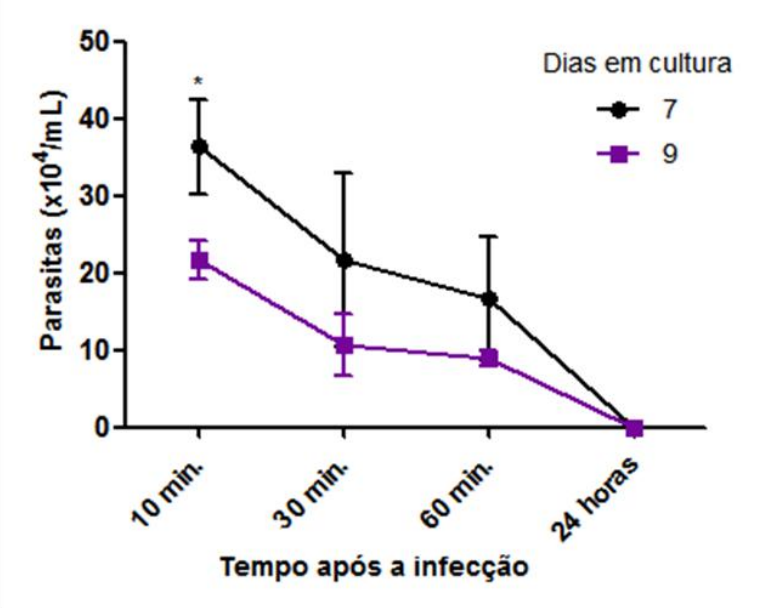

B

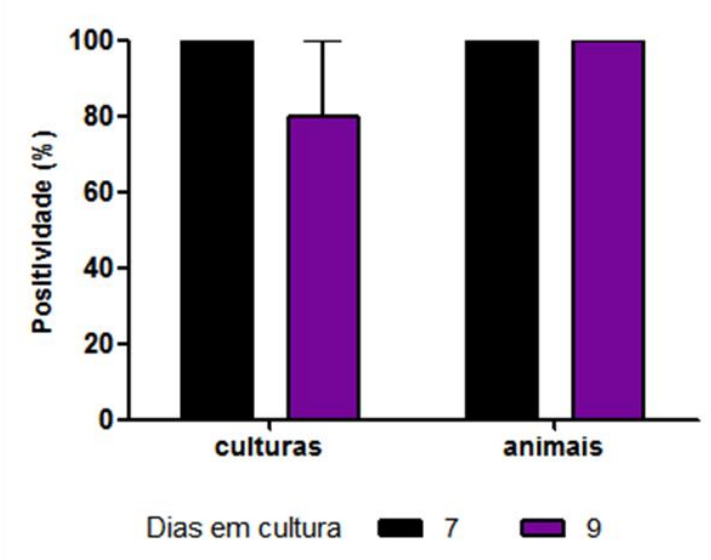

Camundongos C57BI/6 WT inoculados i.v. com $2 \times 10^{6}$ formas tripomastigotas obtidos de diferentes dias de cultura. (A) Parasitemia patente comparativa. (B) Parasitemia subpatente avaliada por hemocultura com alíquotas de $5 \mu \mathrm{l}$ (em quintuplicata) do sangue dos animais infectados por 14 dias. Dados expressos como Média $\pm S D$ de um experimento com 3 animais em cada grupo (Two-way ANOVA: ${ }^{*} p<0,05$ em relação ao 9을 dia de cultura).

\subsection{Análise da parasitemia após inoculação pela via intravenosa de parasitas da cepa Y de Trypanosoma cruzi}

Outra cepa de T. cruzi objeto de estudo do nosso laboratório é a cepa Y. Dentre as características que a diferenciam das cepas de baixa virulência, como o clone Sylvio X10/4, está sua multiplicação rápida e alta mortalidade que induz em diversas linhagens de camundongos (LOPES; PRADO JÚNIOR, 2007). Assim, na infecção experimental de camundongos normais, a infecção por parasitas da cepa $Y$ determina altas parasitemias logo na primeira semana da infecção e frequentemente leva à morte do hospedeiro na fase aguda (MARINHO et al., 2004). Devido à diferença na virulência dentre estas duas cepas procuramos avaliar a parasitemia logo após a inoculação i.v. com $T$. cruzi da cepa $Y$ (oriundos do dia 7 de cultura de células). Podemos observar que na infecção com parasitas da cepa $Y$, o número aproximado de parasitas circulantes aos 60 minutos da inoculação é semelhante ao obtido na infecção por parasitas do clone Sylvio X10/4 (ver na Figura 4A os dados do $7^{\circ}$ dia em cultura), e após 24 horas não foram mais encontrados parasitas no sangue (Fig. 5A), mas a hemocultura mostrou parasitemia subpatente às 48 horas (Fig. 5B). 
Figura 5 - Parasitemias dos camundongos inoculados pela via intravenosa com formas tripomastigotas de cultura da cepa $Y$

A

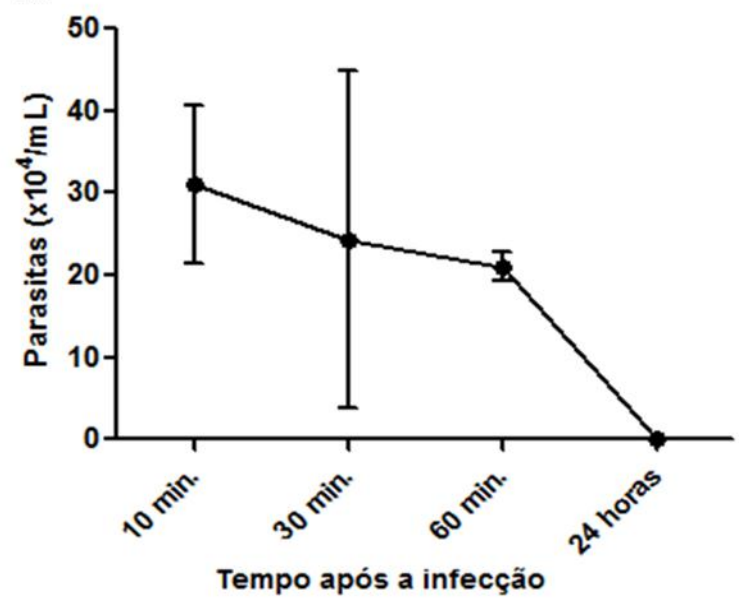

B

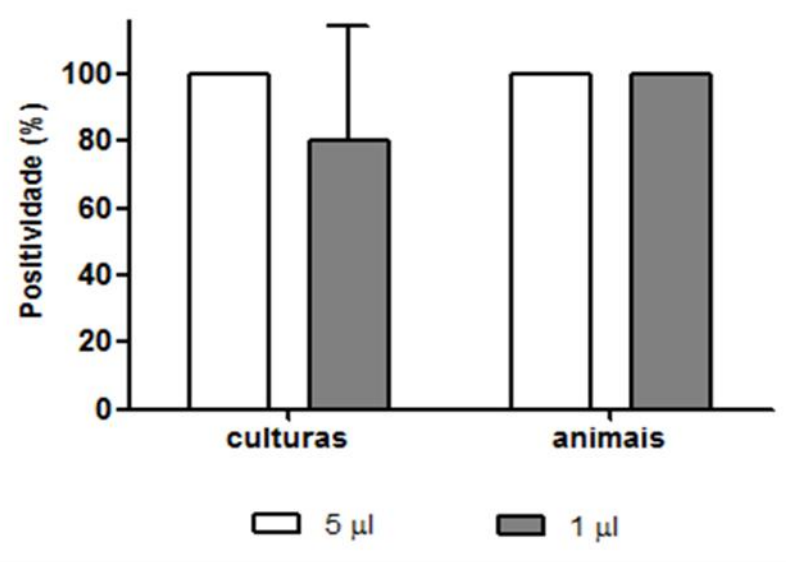

Camundongos C57BI/6 WT infectados i.v. com $2 \times 10^{6}$ formas tripomastigotas de cultura da cepa Y. (A) Curva de parasitemia patente. (B) Parasitemia subpatente avaliada por hemocultura após 48 horas de infecção (alíquotas de $5 \mu \mathrm{l}$ e $1 \mu \mathrm{l}$ de sangue de cada um dos animais em quintuplicata). Dados expressos como Média $\pm S D$ de um experimento com 3 animais.

\subsection{Estudo comparativo da parasitemia de camundongos inoculados pela via intravenosa com $T$. cruzi clone Sylvio X10/4 ou cepa $Y$ isolados do sangue de animais imunodeficientes}

Variações na virulência do $T$. cruzi e no seu comportamento em um hospedeiro vertebrado já foram relatadas quando estes foram mantidos sob condições experimentais em laboratório por longos períodos (CONTRERAS et al., 1994). Para avaliar se as semelhanças entre o clone Sylvio $X 10 / 4$ e a cepa $Y$ mostradas nos gráficos anteriores decorriam da utilização de parasitas procedentes de cultura in vitro em células LLCMK2, realizamos infecções com formas tripomastigotas (Sylvio X10/4 e Y) isolados de camundongos infectados. Para estas experiências os parasitas foram obtidos do sangue de camundongos C57BI/6 SCID ou RAG2KO infectados, uma vez que somente nestas condições a infecção pelo clone Sylvio X10/4 resulta na presença de parasitas circulantes que podem ser isolados por centrifugação do sangue heparinizado. Mais ainda, o fato dos animais C57BI/6 SCID ou RAG2KO serem deficientes de linfócitos T e B permite obtermos parasitas desprovidos de anticorpos na sua superfície, anticorpos que poderiam 
acelerar a saída do parasita do sangue após serem inoculados nos camundongos normais.

\subsubsection{Infecção com T. cruzi clone Sylvio X10/4}

Observamos que a saída do sangue do T. cruzi clone Sylvio X10/4 independe da sua origem. Assim, a curva de parasitemia de camundongos C57BI/6 WT inoculados pela via intravenosa com formas tripomastigotas isolados do sangue de camundongos imunodeficientes foi semelhante àquela obtida na inoculação com parasitas de cultura, com queda progressiva da parasitemia nos primeiros 60 minutos e ausência das formas tripomastigotas circulantes no sangue após 24 horas (Fig. 6).

Figura 6 - Parasitemia comparativa clone Sylvio X10/4

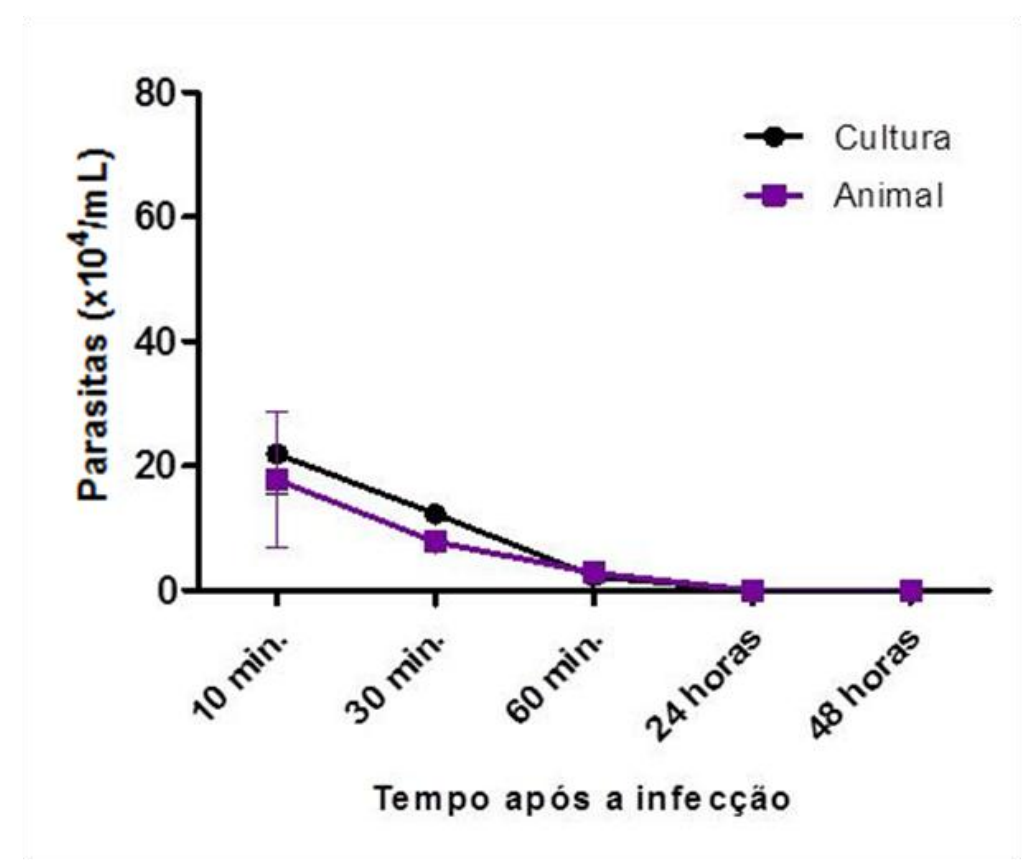

Curvas de parasitemia de animais C57BI/6 WT inoculados i.v. com $2 \times 10^{6}$ formas tripomastigotas do clone Sylvio X10/4 provenientes de cultura in vitro em células LLCMK2 ou isolados do sangue de animais imunodeficientes. Dados expressos como Média $\pm S D$ de um experimento com 3 animais em cada grupo.

\subsubsection{Infecção com T. cruzi cepa $Y$}

Nos animais inoculados i.v. com parasitas da cepa $Y$ obtidos de cultura ou isolados do sangue de animais imunodeficientes observamos que, 10 minutos após 
a infecção, há uma diferença significativa entre as parasitemias com, aproximadamente, duas vezes mais parasitas circulantes quando estes foram isolados do sangue de animais imunodeficientes. Além disso, nos animais inoculados com parasitas da cepa $Y$ obtidos de animal imunodeficiente pôde ser constatada, pela primeira vez, a presença de parasitas no sangue após 24 horas de infecção (Fig. 7).

Figura 7 - Parasitemia comparativa cepa $Y$

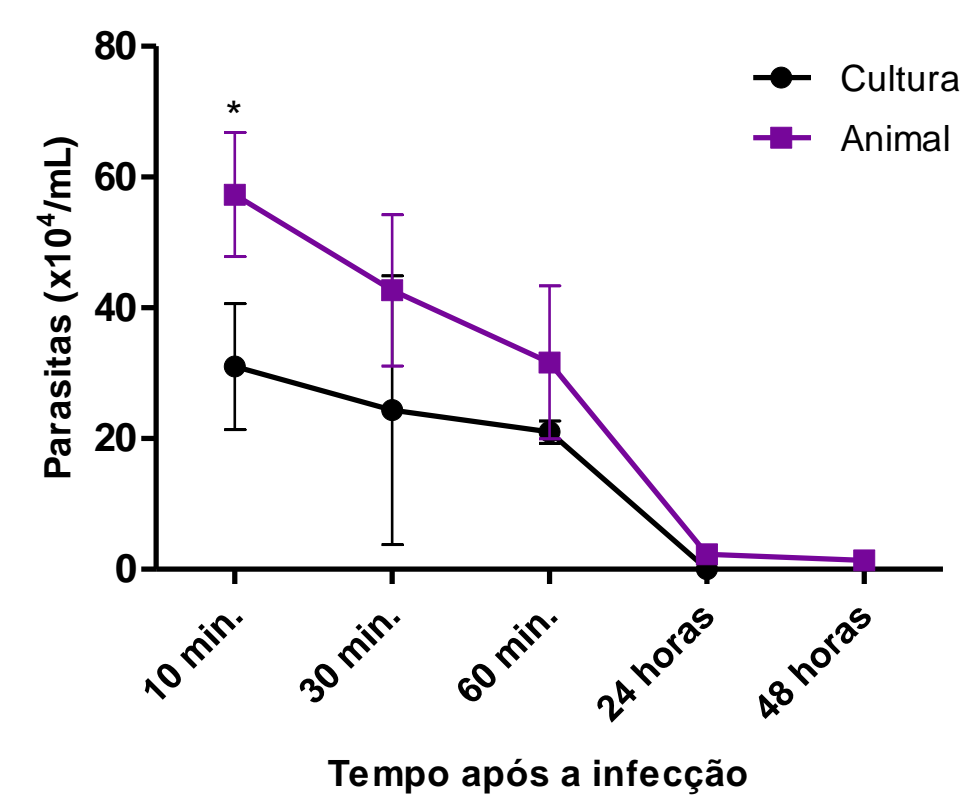

Curvas de parasitemia de animais C57BI/6 WT inoculados i.v. com $2 \times 10^{6}$ formas tripomastigotas da cepa $Y$ provenientes de cultura in vitro em células LLCMK2 ou isolados do sangue de animais imunodeficientes. Dados expressos como Média $\pm S D$ de um experimento com 3 animais em cada grupo (Two-way ANOVA: * $p<0,05$ em relação à curva de parasitemia com parasitas de cultura).

\subsection{Análise da carga parasitária em diferentes tecidos}

Com o intuito de avaliar o local onde os parasitas injetados em camundongos normais se encontram após não serem mais observados na corrente sanguínea, animais C57BI/6 WT foram infectados via intravenosa com $2 \times 10^{6}$ formas tripomastigotas do clone Sylvio X10/4 ou da cepa $Y$ obtidos do sangue de animais imunodeficientes infectados. Após 24 horas de infecção os animais foram perfundidos e os órgãos retirados para avaliação da presença do parasita por qRTPCR e cultura em meio LIT. 
De acordo com os nossos achados, a parasitemia subpatente após a inoculação das formas tripomastigotas do clone Sylvio X10/4 pôde ser confirmada por hemocultura (Fig. 8A), indicando que uma pequena fração dos parasitas ainda circula. Já em relação aos órgãos, há uma quantidade maior de cópias de rRNA de T. cruzi no fígado, seguido do baço, comparado aos demais órgãos (Fig. 8B). Para avaliar se os parasitas encontrados nos órgãos estavam vivos, fragmentos dos diferentes órgãos foram macerados e cultivados em meio LIT na forma descrita por Sardinha et al. (2010). Podemos observar que somente havia parasitas vivos no fígado e, em nível inferior, no baço (Fig. 8C).

Figura 8 - Quantificação da carga parasitária por qRT-PCR em diferentes tecidos de animais inoculados pela via intravenosa com parasitas do clone Sylvio X10/4

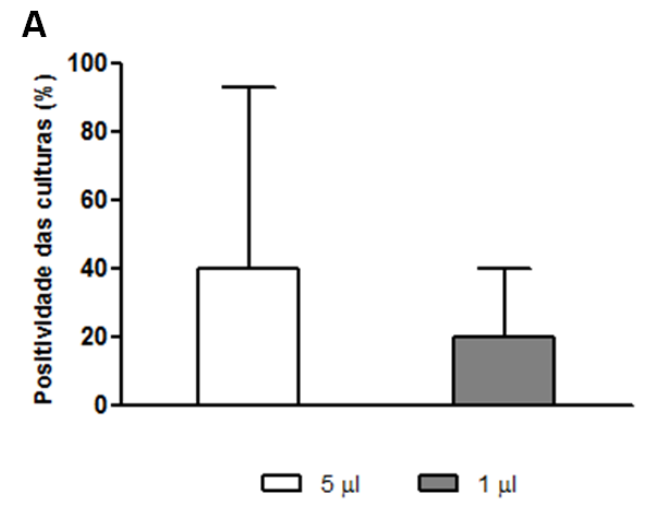

B

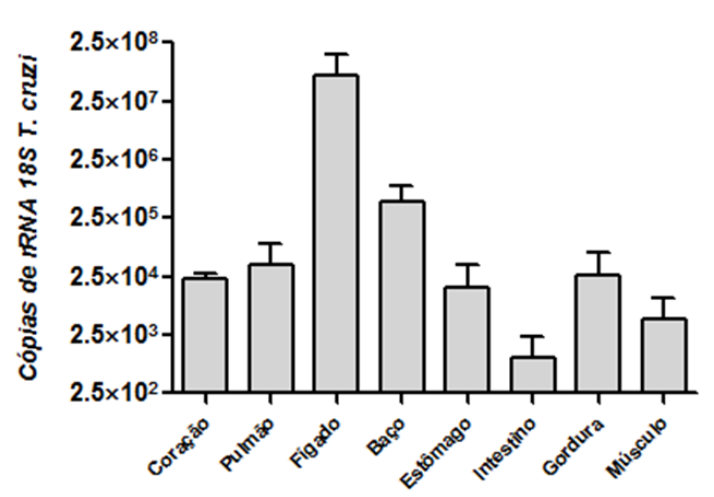

C

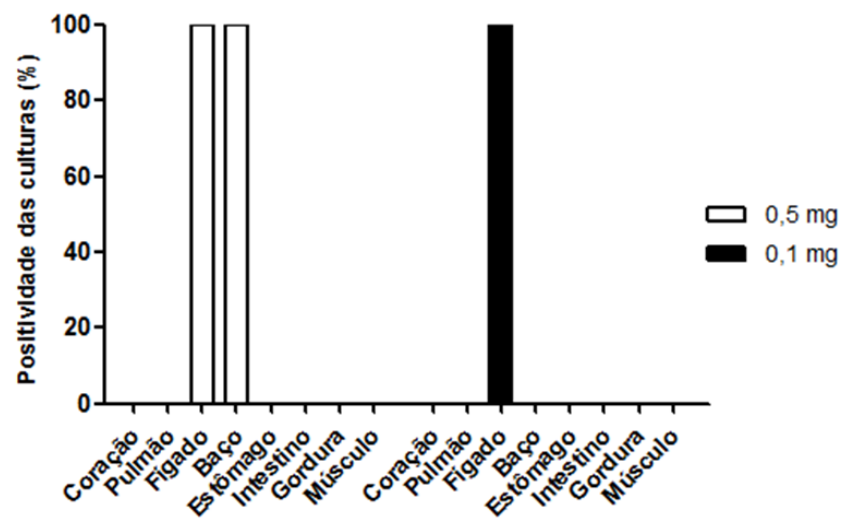

Expressão do gene T. cruzi 18S rRNA em camundongos C57Bl/6 WT após 24 horas da infecção i.v. com $2 \times 10^{6}$ formas tripomastigotas do clone Sylvio $\times 10 / 4$ obtidos do sangue de animais imunodeficientes. (A) Parasitemia subpatente. (B) Expressão do rRNA 18S do T. cruzi calculada

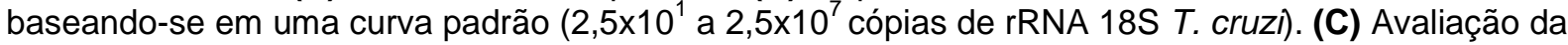
presença de parasitas vivos por cultura em meio LIT (alíquotas de 0,5 mg e 0,1 mg em quintuplicata). Dados expressos como Média $\pm S D$ e são representativos de uma experiência com 3 animais. 
Por outro lado, quando os animais foram inoculados via intravenosa com parasitas da cepa $Y$, observamos que a parasitemia subpatente é mais alta do que a obtida após a inoculação de parasitas do clone Sylvio X10/4, uma vez que no primeiro caso todas as culturas em meio LIT com $1 \mu \mathrm{l}$ de sangue foram positivas (Fig. 9A).

Contudo, de forma semelhante ao observado com parasitas do clone Sylvio $X 10 / 4$, às 24 horas da inoculação dos parasitas da cepa $Y$ pela via intravenosa, o fígado e, em segundo lugar, o baço, são os órgãos com maior presença de rRNA do parasita. Destaca, entretanto, que nos animais inoculados com $T$. cruzi da cepa $Y$ o número de rRNA de $T$. cruzi no baço é menos de dez vezes o exibido pelo fígado, enquanto que nos animais inoculados com parasitas do clone Sylvio X10/4 a quantidade de rRNA do parasita no baço é cerca de cem vezes menor que a do fígado. O aumento relativo na saída de parasitas da cepa Y para o baço também é evidente em termos absolutos, uma vez que o baço dos animais inoculados com parasitas desta cepa apresenta cerca de dez vezes mais cópias de rRNA de T. cruzi do que nos animais inoculados com os parasitas do clone Sylvio X10/4 (Fig. 9B). Finalmente, da mesma forma que visualizado com animais inoculados com parasitas do clone Sylvio X10/4, os únicos órgãos onde encontramos parasitas vivos foram o fígado e baço (Fig. 9C). 
Figura 9 - Quantificação da carga parasitária por qRT-PCR em diferentes tecidos de animais inoculados pela via intravenosa com parasitas da cepa $Y$

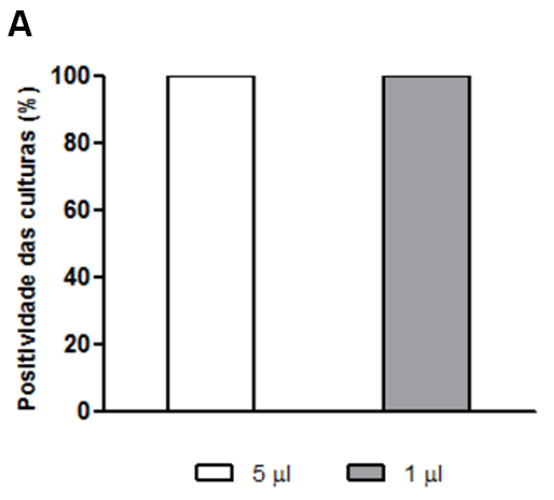

B

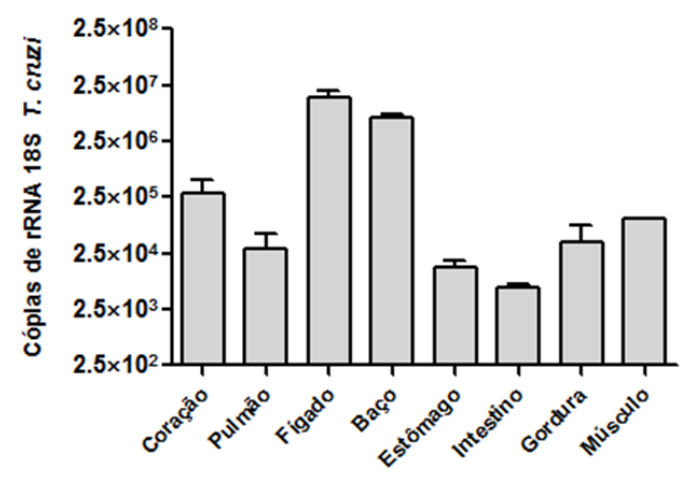

C

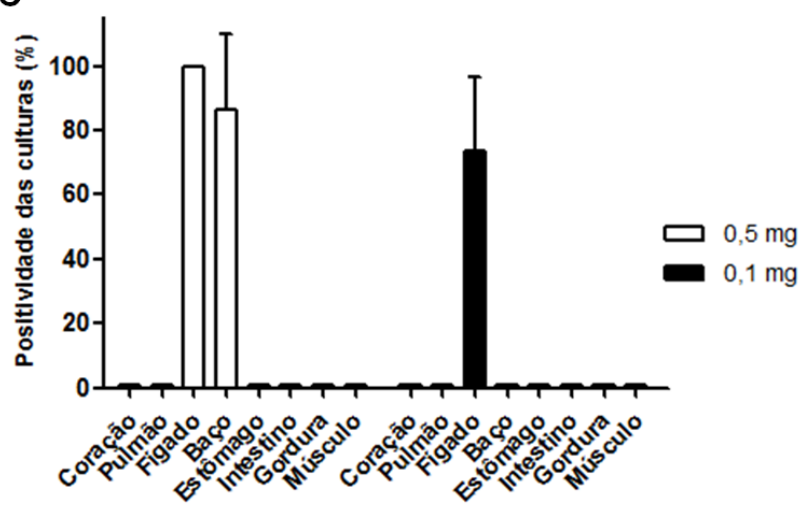

Expressão do gene T. cruzi 18S rRNA em camundongos C57Bl/6 WT após 24 horas da infecção i.v. com $2 \times 10^{6}$ formas tripomastigotas da cepa $Y$ obtidos do sangue de animais imunodeficientes. (A) Parasitemia subpatente. (B) Expressão do rRNA $18 \mathrm{~S}$ do T. cruzi calculada baseando-se em uma curva padrão $\left(2,5 \times 10^{1}\right.$ a $2,5 \times 10^{7}$ cópias de rRNA $18 \mathrm{~S} T$. cruzi). (C) Avaliação da presença de parasitas vivos por cultura em meio LIT (alíquotas de $0,5 \mathrm{mg}$ e $0,1 \mathrm{mg}$ em quintuplicata). Dados expressos como Média $\pm S D$ e são representativos de uma experiência com 3 animais.

\subsection{Papel dos anticorpos na saída do parasita do clone Sylvio X10/4 da corrente sanguínea}

Como primeiro passo na análise das moléculas que poderiam estar envolvidas na ausência do $T$. cruzi clone Sylvio X10/4 no sangue, avaliamos o papel dos anticorpos naturais. Para isto comparamos as curvas de parasitemias patentes de animais C57BI/6 SCID (que não possuem linfócitos T nem B, portanto carentes de anticorpos) e C57BI/6 WT, logo após serem inoculados, via intravenosa, com $2 \times 10^{6}$ formas tripomastigotas do clone Sylvio X10/4. Observamos que, assim como ocorre nos camundongos C57BI/6 WT, os animais C57BI/6 SCID inoculados apresentam aos 30 minutos da inoculação uma rápida queda do número de parasitas na corrente sanguínea, baixo número destes após 1 hora e ausência de 
parasitemia patente após 24 horas (Fig. 10A). As parasitemias subpatentes também foram analisadas por hemocultura e, apesar de às 48 horas os níveis das duas linhagens ainda se manterem semelhantes (Fig. 10B), com 72 horas de infecção as parasitemias dos animais WT se mostraram maiores do que as apresentadas pelo SCID (Fig. 10C).

Figura 10 - Análise comparativa das parasitemias de camundongos WT e SCID inoculados pela via intravenosa com $T$. cruzi clone Sylvio X10/4 para avaliação do papel dos anticorpos naturais

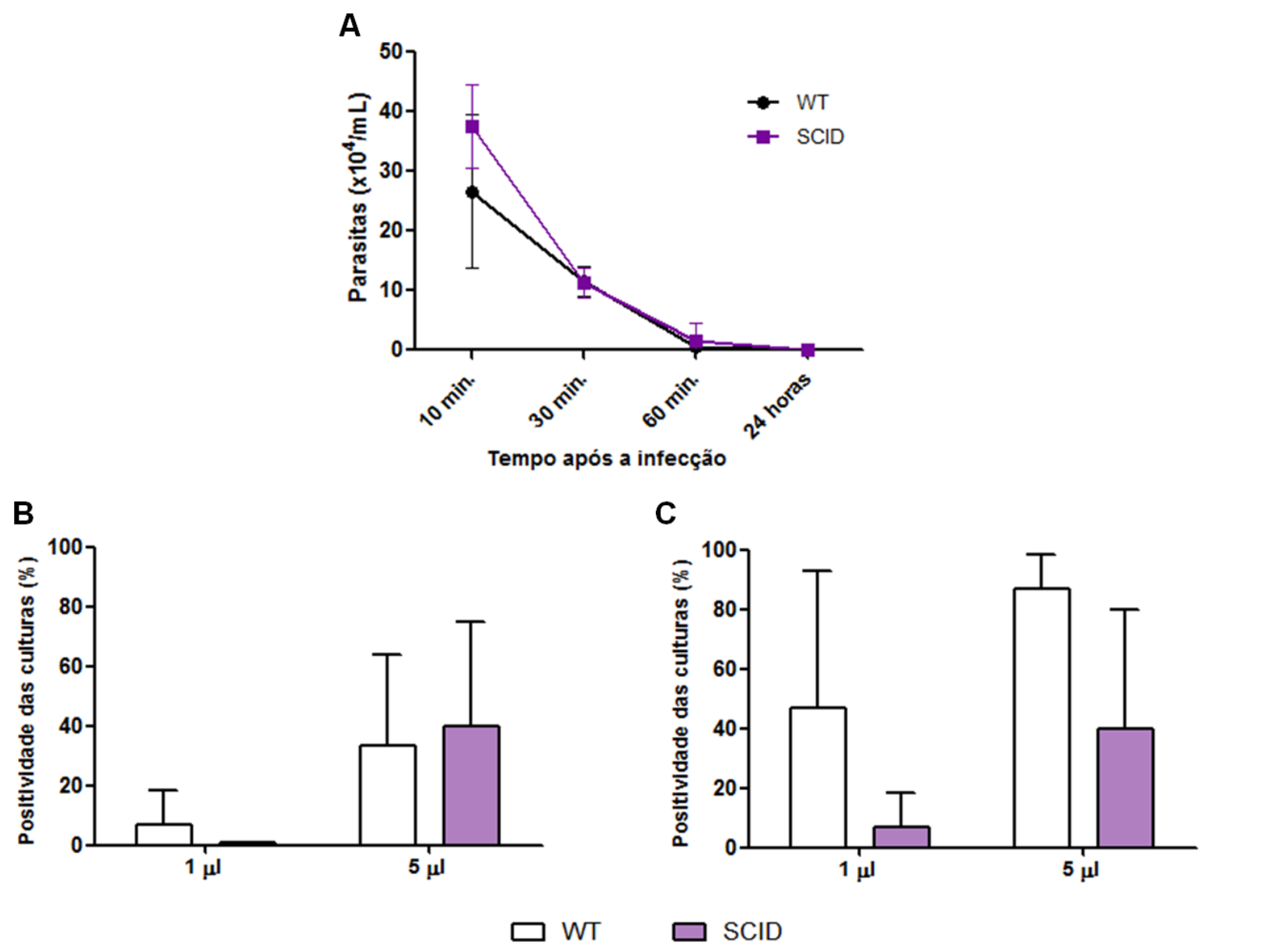

Camundongos C57BI/6 WT e C57BI/6 SCID inoculados i.v. com $2 \times 10^{6}$ formas tripomastigotas do clone Sylvio X10/4 de cultura. (A) Curvas comparativas de parasitemia. (B) Parasitemia subpatente após 48 horas da infecção avaliada por hemocultura em meio LIT. (C) Parasitemia subpatente após 72 horas da infecção avaliada por hemocultura em meio LIT. Hemocultura em meio LIT com alíquotas de $5 \mu \mathrm{l}$ e $1 \mu \mathrm{l}$ de sangue de todos os animais em quintuplicata. Dados expressos como Média $\pm S D$ de um experimento com 3 animais em cada grupo. 


\subsection{Papel do sistema complemento na saída do sangue de parasitas do clone Sylvio X10/4 em animais recém-infectados pela via intravenosa}

Para avaliarmos a eventual participação do sistema complemento na remoção do parasita recém-injetado na corrente sanguínea, animais C57BI/6 WT foram tratados com CVF, para eliminar a atividade do sistema complemento, ou com PBS antes de serem inoculados com o parasita.

\subsubsection{Papel do sistema complemento na saída do sangue do T. cruzi clone Sylvio X10/4 provenientes de cultura celular}

A parasitemia foi analisada em camundongos $\mathrm{C} 57 \mathrm{BI} / 6 \mathrm{WT}$ inoculados i.v. com $2 \times 10^{6}$ formas tripomastigotas de cultura, três horas após a segunda dose de CVF ou PBS. Como controle da ação efetiva do CVF, o sangue dos animais antes e após o tratamento foi submetido a um teste de hemólise para verificar a presença de componentes do sistema complemento. Desta forma, pudemos confirmar que o tratamento com CVF eliminou completamente o complemento nos animais tratados (Fig. 11A e 11B). 
Figura 11 - Avaliação da depleção de complemento pelo teste de hemólise

A

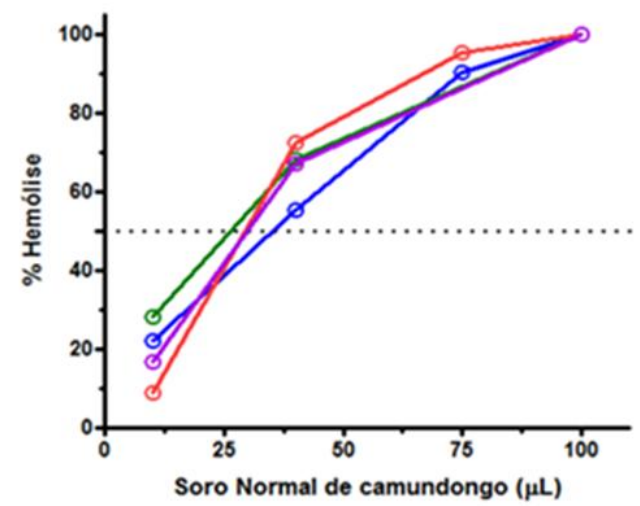

B

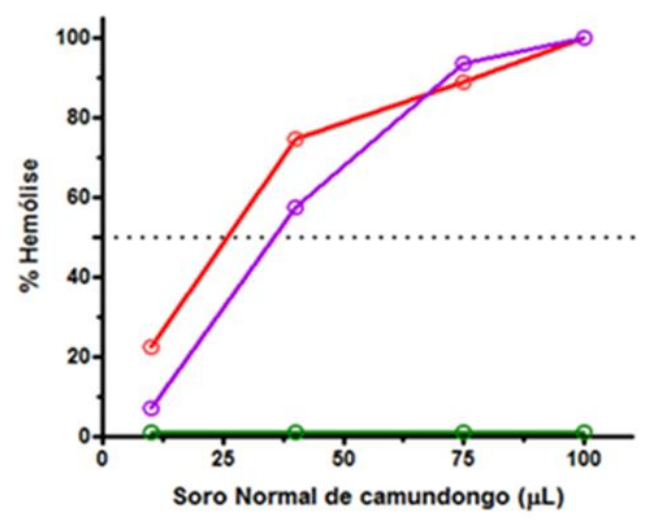

$$
\ominus \mathrm{CVF} \quad \theta \mathrm{CVF} \quad \theta \text { Controle } \theta \text { Controle }
$$

Curvas da indução de hemólise pelo soro de camundongos tratados com CVF ou PBS para verificar a presença de atividade lítica do complemento. (A) Teste de hemólise antes dos tratamentos. (B) Teste de hemólise após o tratamento com CVF ou PBS (controles). Número de animais em cada grupo igual a 2.

Após confirmarmos que o tratamento com CVF acaba completamente com o sistema complemento, os animais tratados e controles foram inoculados com as formas tripomastigotas do clone Sylvio X10/4 de cultura. Nos tempos subsequentes à inoculação, a parasitemia dos animais tratados com CVF mostrou-se semelhante à dos animais controles (Fig. 12). 
Figura 12 - Comparação do perfil da parasitemia em camundongos desprovidos de sistema complemento e camundongos controle que foram inoculados pela, via intravenosa, com parasitas do clone Sylvio X10/4 provenientes de cultura celular

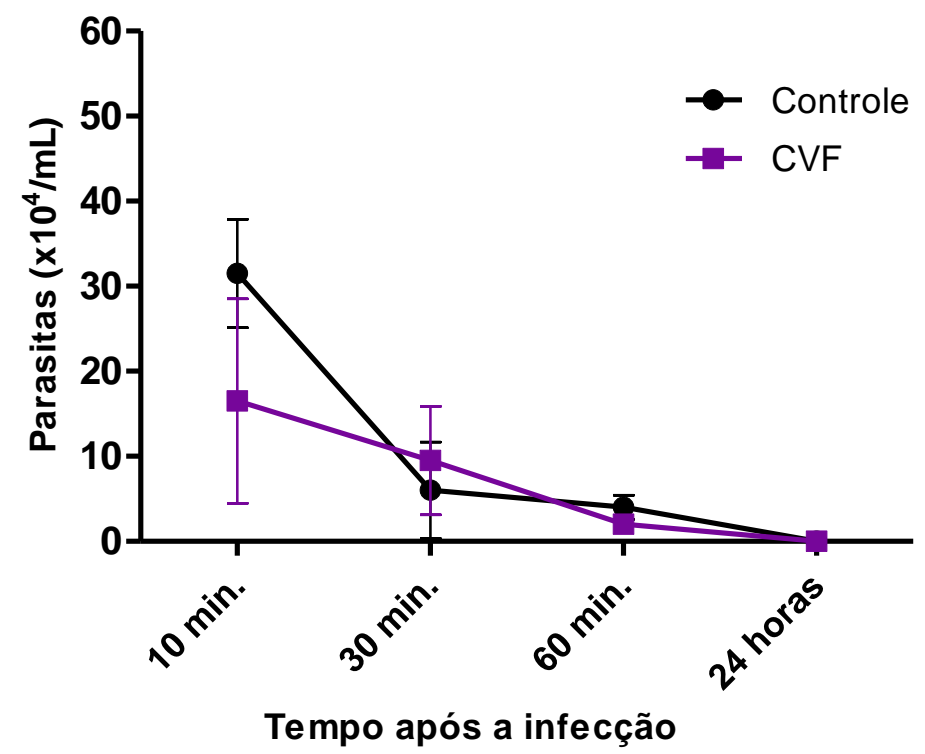

Curvas de parasitemia de animais C57BI/6 WT tratados com CVF ou PBS (controle) e infectados i.v. com $2 \times 10^{6}$ formas tripomastigotas de cultura do clone Sylvio X10/4. Resultados expressos como a Média \pm SD dos valores obtidos de um experimento realizado com dois animais em cada grupo.

\subsubsection{Papel do sistema complemento na saída do sangue do T. cruzi clone Sylvio X10/4 provenientes do sangue de animais imunodeficientes}

Com o intuito de avaliar se a ativação do complemento participaria na parasitemia com $T$. cruzi proveniente do sangue de animais imunodeficientes, animais tratados com CVF e controle foram infectados i.v. com $2 \times 10^{6}$ formas tripomastigotas Sylvio X10/4 isolados do sangue de camundongos C57BI/6 RAG2KO previamente infectados. Como citado anteriormente, este modelo permite isolar parasitas circulantes desprovidos de anticorpos na sua superfície.

Após comprovação que o tratamento com CVF eliminou a ação do sistema complemento pelo teste de hemólise (Fig. 13), observamos que nos primeiros 10 minutos após a infecção houve uma diferença significativa, com aproximadamente duas vezes mais parasitas circulantes no sangue dos animais desprovidos de complemento do que no grupo controle; após este período houve uma queda na parasitemia em ambos os grupos que se manteve semelhante até a última medição (Fig. 14). 
Figura 13 - Teste de hemólise

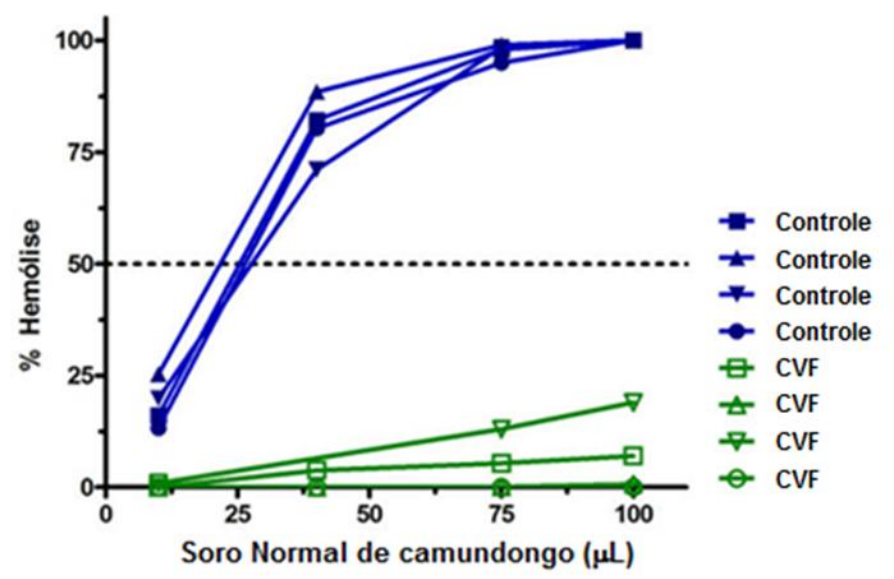

Curvas da indução de hemólise pelo soro de camundongos após o tratamento com CVF ou PBS (controles) para verificar a presença de atividade lítica do complemento. Número de animais em cada grupo igual a 4.

Figura 14 - Comparação do perfil da parasitemia após eliminação do sistema complemento

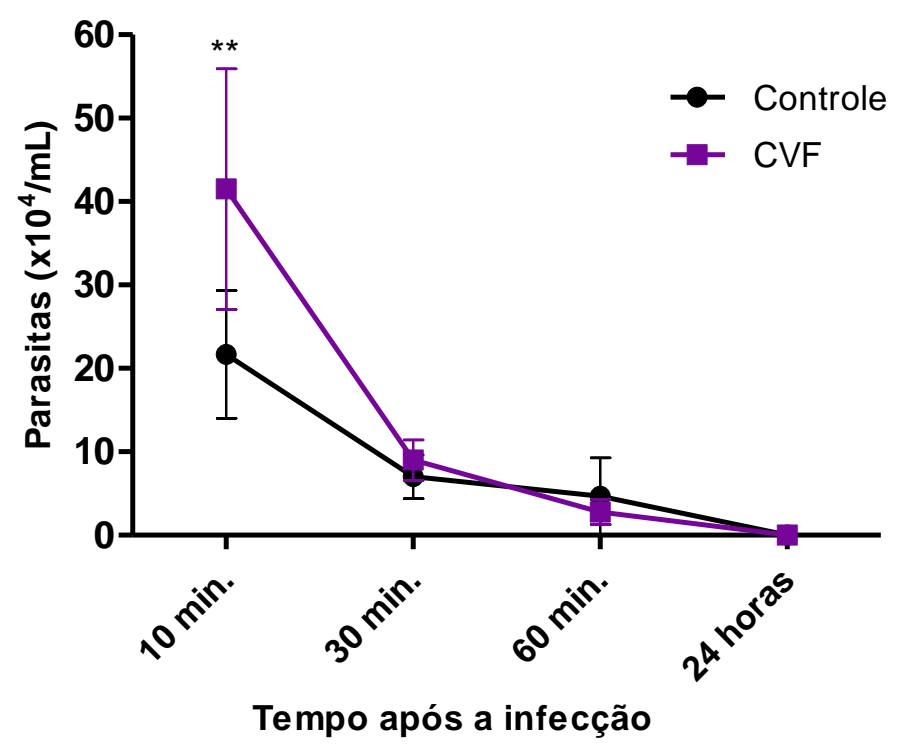

Curvas de parasitemia de animais C57BI/6 WT tratados com CVF ou PBS (controles) que foram infectados i.v. com $2 \times 10^{6}$ formas tripomastigotas do clone Sylvio X10/4 provenientes de animais imunodeficientes C57BI/6 RAG2KO previamente infectados. Resultados expressos como a Média \pm SD dos valores obtidos de um experimento realizado com três animais de cada grupo (Two-way ANOVA: ${ }^{* *} \mathrm{p}<0,01$ em relação ao grupo controle).

\subsection{Papel do IFN- $\gamma$ na parasitemia de animais infectados com o clone Sylvio $\mathrm{X} 10 / 4$}


Devido a importante ação do IFN- $\gamma$ principalmente no inicio da infecção, nosso próximo passo foi avaliar seu papel na infecção com T. cruzi clone Sylvio X10/4. Para isso, infectamos animais C57BI/6 WT e C57BI/6 IFN- $\gamma \mathrm{KO}$, via intravenosa, com $2 \times 10^{5}$ formas tripomastigotas do clone Sylvio X10/4 e, em diferentes dias, dois animais de cada grupo foram sacrificados e a parasitemia avaliada. Com este experimento pudemos verificar que a infecção de animais IFN- $\gamma \mathrm{KO}$ com parasitas do clone Sylvio X10/4 exibe um perfil intermitente de parasitemia patente nos primeiros 30 dias (Fig. 15).

Figura 15 - Parasitemia comparativa de animais WT e IFN- $\gamma \mathrm{KO}$

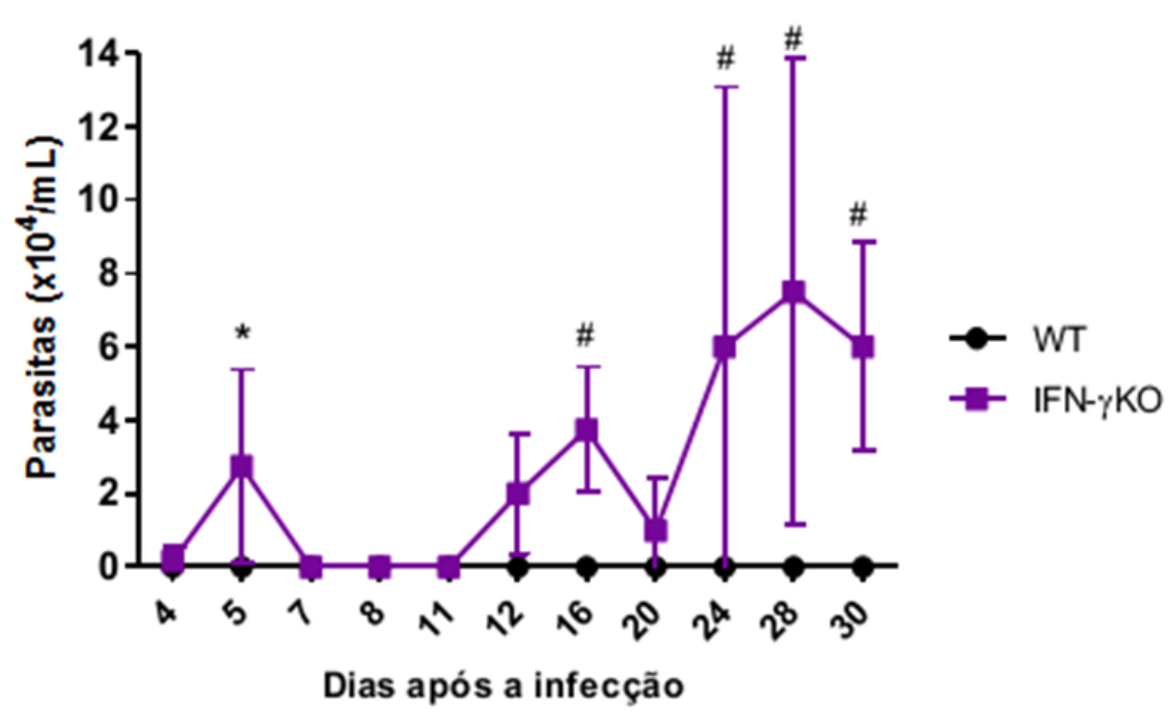

Curvas de parasitemia de animais C57BI/6 WT e C57BI/6 IFN- $\gamma$ KO infectados i.v. com $2 \times 10^{5}$ formas tripomastigotas de cultura do clone Sylvio X10/4. Resultados expressos como Média \pm SD dos valores obtidos de dois animais de cada grupo, por dia, em dois experimentos. Número de animais em cada experimento igual a 10 por grupo (Two-way ANOVA: ${ }^{*} p<0,05$ e $\# p<0,001$ em relação ao grupo WT).

Além disso, os animais IFN- $\gamma \mathrm{KO}$ se mostraram muito suscetíveis, com a morte de todos os camundongos em até 40 dias após a infecção (Fig. 16). 
Figura 16 - Sobrevivência de animais WT e IFN- $\gamma$ KO

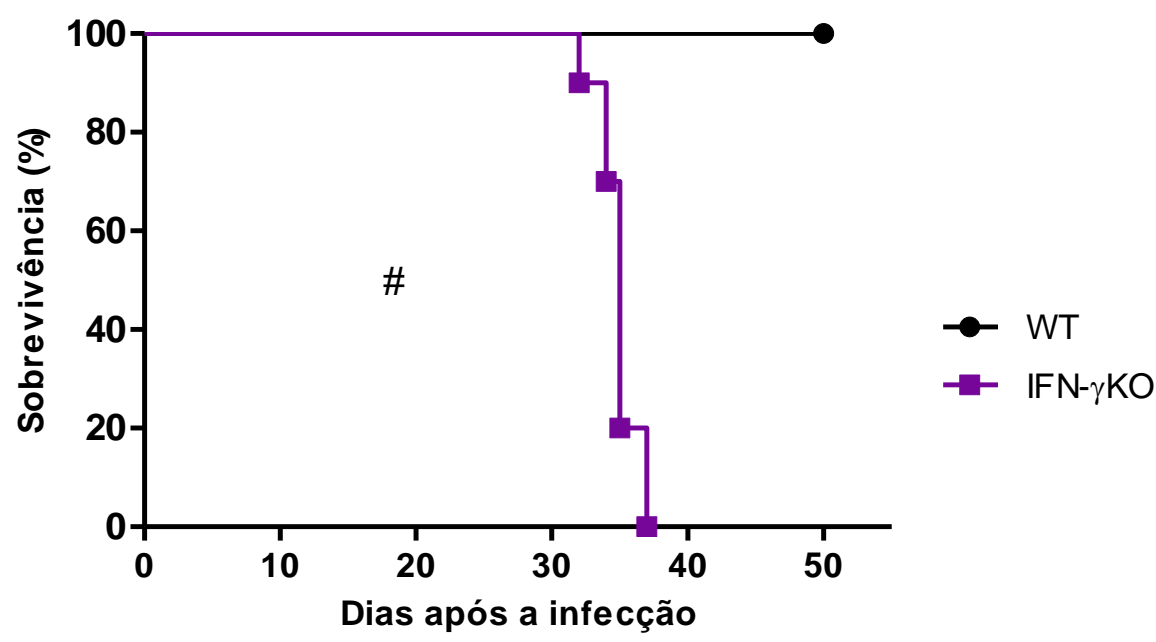

Curvas de sobrevivência de animais C57BI/6 WT e C57BI/6 IFN- $\gamma \mathrm{KO}$ infectados i.v. com $2 \times 10^{5}$ formas tripomastigotas do clone Sylvio X10/4 provenientes de cultura em células LLCMK2. Resultados expressos como Média $\pm S D$ de um experimento realizado com 10 animais em cada grupo (Log-rank (Mantel-Cox): \#p<0,001 em relação aos animais WT).

\subsection{Avaliação de proteínas de fase aguda em animais WT e IFN- $\gamma \mathrm{KO}$ infectados com parasitas do clone Sylvio X10/4}

Em diversos processos inflamatórios de etiologia diversa a produção de citocinas pró-inflamatórias determina o aumento nos níveis das proteínas de fase aguda. Procurando uma explicação para o padrão oscilatório de parasitemia observado na infecção de animais C57BI/6 IFN- $\gamma \mathrm{KO}$ por parasitas do clone Sylvio $\mathrm{X} 10 / 4$, cogitamos que isto pudesse estar relacionado com uma ativação descontínua da imunidade inata (MARINHO et al., 2009), que secundariamente resultasse em descontinuidade na produção de proteínas de fase aguda. Neste contexto, fomos avaliar a produção destas proteínas na infecção por animais IFN- $\gamma \mathrm{KO}$ e WT (todos com background $\mathrm{C} 57 \mathrm{BI} / 6$ ), focando nossos trabalhos na quantificação sérica dos níveis da proteína $C$ reativa (CRP), amiloide $P$ sérica (SAP), amiloide $A$ sérica (SAA) e lectina ligante de manose (MBL), pois são moléculas que têm papel na resposta imunológica, com a capacidade de opsonizar vários microorganismos e ativar a cascata do complemento. Assim, camundongos WT e IFN- $\gamma \mathrm{KO}$ foram infectados com $2 \times 10^{5}$ formas tripomastigotas, via intravenosa, e em diferentes dias dois animais de cada grupo foram sacrificados e o soro coletado para determinação da concentração das proteínas pelo teste imunoenzimático ELISA. 
Em nossa avaliação da CRP encontramos níveis séricos aumentados nos animais IFN- $\gamma \mathrm{KO}$, comparado aos WT, apenas no $13^{\circ}$ dia p.i., e semelhantes em ambas as linhagens nos demais dias do período analisado. Vale ressaltar que devido à baixa concentração sérica desta proteína em camundongos (WHITEHEAD et al., 1990), os níveis detectados no soro dos animais WT e IFN- $\gamma$ KO infectados foram muito baixos (Fig. 17A).

Diferentemente, os níveis da proteína SAP aumentaram nas duas linhagens após a infecção. No entanto, nos dias 13, 18 e 35 do período analisado um aumento significativamente maior foi observado nos animais IFN- $\gamma \mathrm{KO}$ em relação aos animais selvagens. O aumento desta proteína nos animais WT se manteve até o $13^{\circ}$ dia p.i., mas foi seguido de uma queda que atingiu o nível dos animais não infectados por volta do dia 18 de infecção (Fig.17B).

De forma semelhante a SAP, nos animais IFN- $\gamma$ KO infectados foi observado um aumento significativo nos níveis da SAA, de aproximadamente mais de dez vezes, no $13^{\circ}$ e $18^{\circ}$ dia de infecção, em relação ao grupo WT. Os animais selvagens mostraram aumento de SAA até o dia 8 p.i. (em relação ao grupo não infectado), seguido de uma leve queda e de um novo aumento no $35^{\circ}$ dia (Fig. 17C).

Finalmente, em relação à $\mathrm{MBL}$, os níveis desta proteína nos animais IFN- $\gamma \mathrm{KO}$ se mostraram significativamente mais altos a partir do $13^{\circ}$ dia de infecção, enquanto que os valores desta proteína no grupo WT não apresentaram alteração ao longo do tempo avaliado (Fig. 17D). 
Figura 17 - Quantificação de proteínas de fase aguda em animais WT e IFN- $\gamma \mathrm{KO}$

A

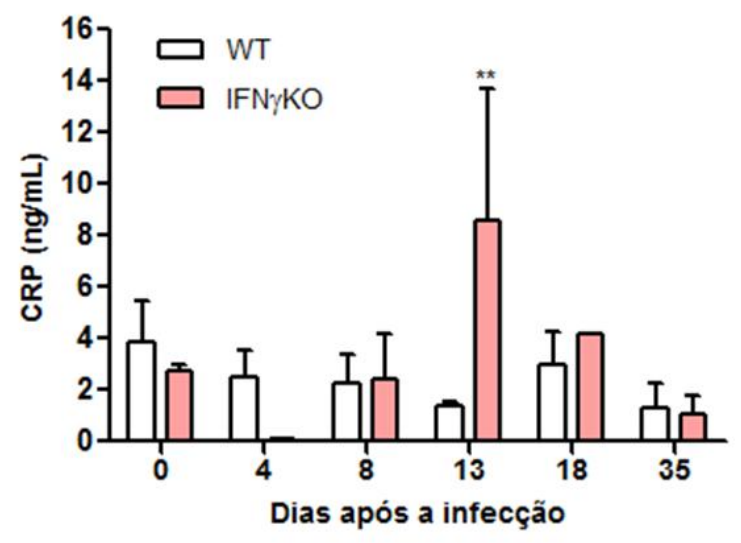

B

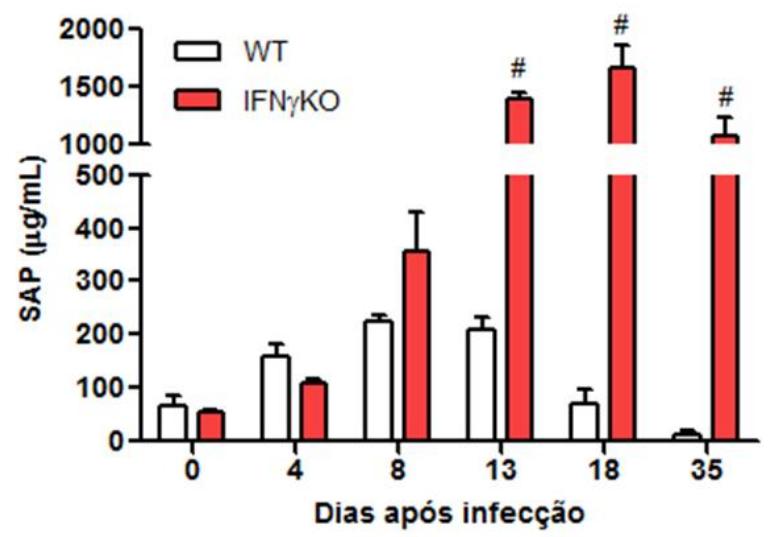

D

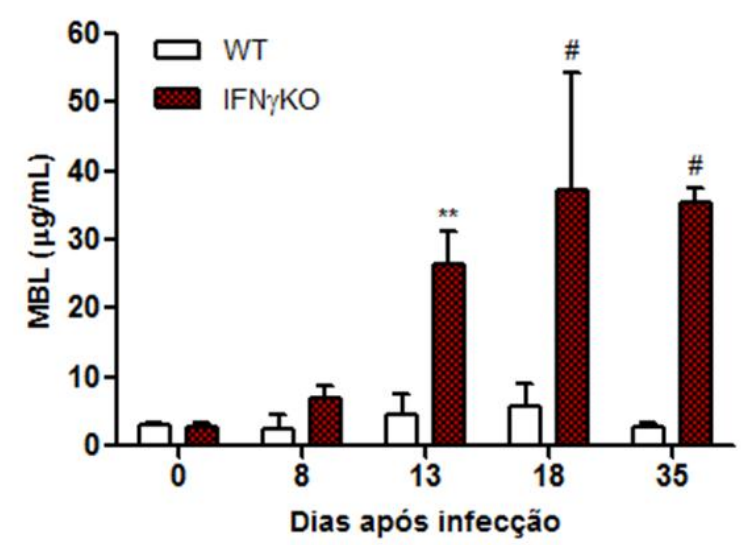

Concentração de proteínas no soro de animais C57BI/6 WT e C57BI/6 IFN- $\gamma$ KO infectados i.v. com $2 \times 10^{5}$ formas tripomastigotas de cultura do clone Sylvio X10/4. (A) Níveis de CRP. (B) Níveis de SAP. (C) Níveis de SAA. (D) Níveis de MBL. Resultados expressos como a Média $\pm S D$ dos valores obtidos de dois experimentos com animais não infectados (dia 0 ) e infectados, avaliando-se dois animais de cada grupo por dia. Número total de animais em cada grupo igual a 13 (Two-way ANOVA: ** $<<0,01$ e $\# p<0,001$ IFN- $\gamma \mathrm{KO}$ em relação ao grupo WT).

\subsection{Mortalidade de animais deficientes em linfócitos B e na molécula CD28 infectados com parasitas do clone Sylvio X10/4}

Como complemento aos nossos estudos estimando a ação dos anticorpos naturais logo no inicio da infecção por formas tripomastigotas do clone Sylvio X10/4, avaliamos a importância de anticorpos específicos no decurso da infecção, pois durante a infecção pelo $T$. cruzi há uma forte resposta humoral evidenciada pela presença de anticorpos específicos (STEEL; WHITEHEAD, 1994), principalmente do tipo IgG2a (TAKEHARA et al., 1981), e estes participam ativamente na saída dos 
parasitas do sangue (UMEKITA; TAKEHARA; MOTA, 1988). Para tanto, escolhemos camundongos C57BI/6 BKO para este experimento devido à ausência de qualquer classe de anticorpos nestes animais, visto que carecem de linfócitos B (KUMAR; TARLETON, 1998). Desta forma, verificamos se haveria diferença na sobrevivência de animais C57BI/6 WT e C57BI/6 BKO machos e fêmeas infectados pela via intravenosa com $2 \times 10^{5}$ formas tripomastigotas de cultura do clone Sylvio X10/4. Devido à ausência de animais C57BI/6 WT machos para o experimento, utilizamos animais $\mathrm{C} 57 \mathrm{BI} / 6 \mathrm{BKO}$ heterozigotos, que apresentam níveis normais de anticorpos (KITAMURA et al., 1991). Assim, encontramos que os animais machos BKO foram mais susceptíveis, morrendo todos eles até o trigésimo dia de infecção, enquanto que as fêmeas morreram entre os dias 55 e 70. Além disso, como esperado, os animais WT fêmeas e os animais heterozigotos $\left(\mathrm{BKO}^{+/}\right)$machos não morreram (Fig. 18).

Figura 18 - Sobrevivência de animais WT e BKO

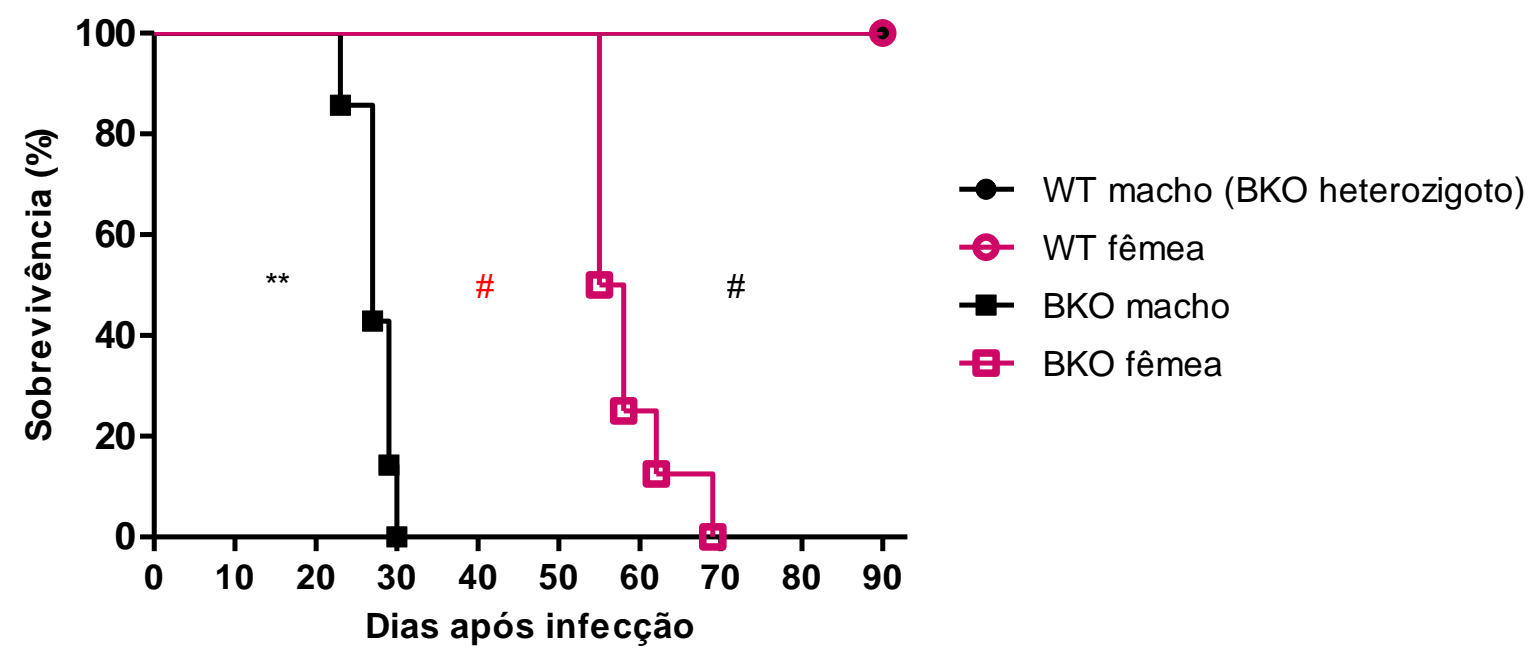

Curvas de sobrevivência de animais C57BI/6 WT, C57BI/6 BKO heterozigotos e C57BI/6 BKO homozigotos infectados i.v. com $2 \times 10^{5}$ formas tripomastigotas do clone Sylvio X10/4 provenientes de cultura em células LLCMK2. Resultado expresso como a Média $\pm S D$ dos valores obtidos de dois experimentos realizados com 5 animais C57BI/6 BKO heterozigotos (WT) macho, 7 animais C57BI/6 BKO macho, 12 animais C57BI/6 WT fêmea e 8 animais C57BI/6 BKO fêmea. (Log-rank (Mantel-Cox): ${ }^{* *} p=0,001$ entre os machos das duas linhagens; $\# p<0,0001$ entre as fêmeas das duas linhagens; $\# p<0,0001$ entre os dois grupos da linhagem BKO).

Além dos animais imunodeficientes em células $B$, adicionamos a estes estudos animais deficientes para a molécula co-estimuladora CD28, uma vez que sinais co-estimulatórios mediados por esta molécula parecem ser indispensáveis 
para a ativação de células T CD4 ${ }^{+}$auxiliares (MARTINS et al., 2004), necessárias na mudança de classe de imunoglobulinas das células B. Em estudos anteriores do laboratório mostramos que a resposta humoral específica dos animais C57BI/6 CD28KO infectados pelo $T$. cruzi clone Sylvio X10/4 é limitada a anticorpos da classe IgM, com ausência de anticorpos da classe lgG (MARINHO et al., 2007).

Assim, camundongos fêmea C57BI/6 WT, C57BI/6 BKO e C57BI/6 deficientes para a molécula CD28 (CD28KO) foram infectados i.v. com $2 \times 10^{5}$ formas tripomastigotas do clone Sylvio X10/4. Nesta experiência, verificamos que apenas os animais $\mathrm{BKO}$, em comparação às demais linhagens, se mostraram altamente susceptíveis, com a morte de todos os animais em até 70 dias após a infecção e, dentro do período de 100 dias p.i., apenas um animal CD28KO infectado morreu (Fig. 19A). Ao longo da avaliação da sobrevivência, nenhuma das linhagens apresentou parasitemia patente (dados não mostrados) e os níveis de parasitemia subpatente se mostraram muito semelhantes nos dois grupos imunodeficientes (Fig. 19B).

Figura 19 - Sobrevivência e parasitemia subpatente de animais WT, BKO e CD28KO infectados pelo T. cruzi clone Sylvio X10/4

A

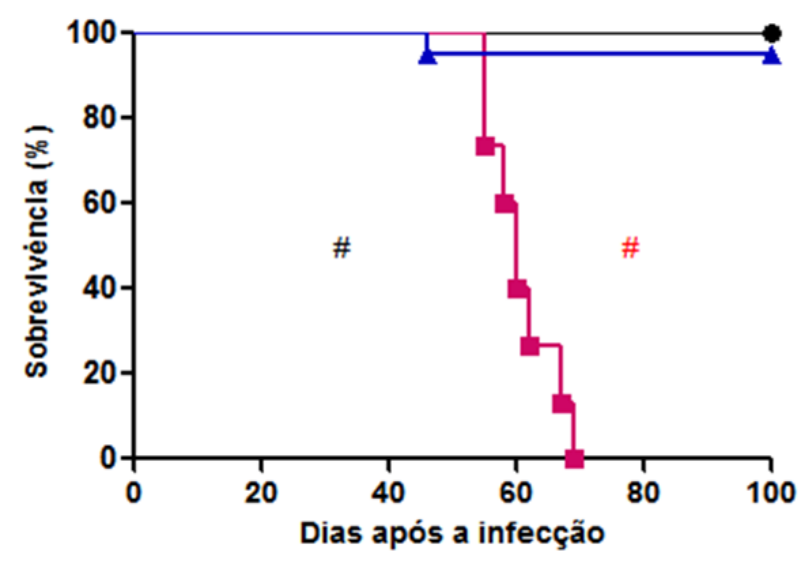

B

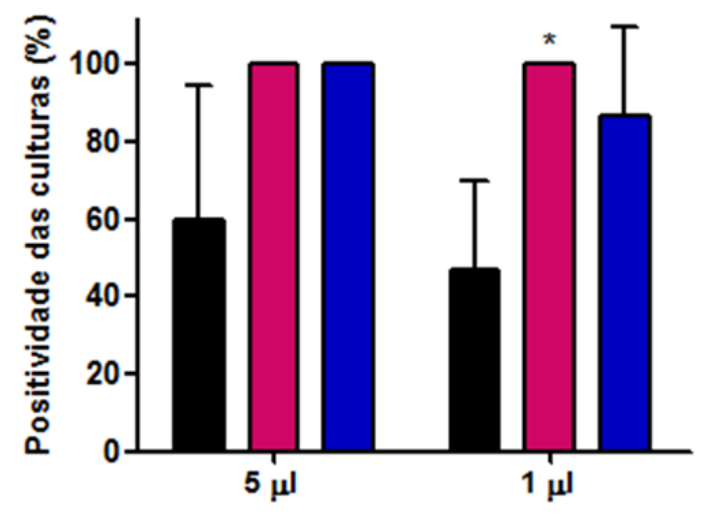

WT

$\mathrm{BKO}$

CD28KO

Sobrevivência e parasitemia de camundongos C57BI/6 WT, C57BI/6 BKO e C57BI/6 CD28KO infectados i.v. com $2 \times 10^{5}$ formas tripomastigotas do clone Sylvio X10/4 provenientes de cultura de células in vitro. (A) Curvas de sobrevivência. (B) Parasitemia subpatente. Resultados expressos como a Média $\pm S D$ dos valores obtidos de dois experimentos realizados com um total de 12 animais C57BI/6 WT, 8 animais C57BI/6 BKO e 12 animais C57BI/6 CD28KO. (Log-rank (Mantel-Cox): $\# p<0,0001$ BKO em relação ao grupo $\mathrm{WT}$; \#p<0,0001 grupo BKO em relação ao grupo CD28KO) (Two-way ANOVA: * $p<0,05$ em relação ao grupo WT). 


\subsection{Avaliação de proteínas de fase aguda em animais WT, BKO e CD28KO infectados com parasitas do clone Sylvio X10/4}

Nosso próximo passou foi verificar se haveria alguma diferença na quantidade de proteínas de fase aguda entre as linhagens C57BI/6 BKO e C57BI/6 CD28KO, visto que nenhuma delas apresenta parasitemia patente ao longo da infecção e os níveis de parasitemia subpatente são semelhantes (Fig. 19B). Desta forma, camundongos fêmeas das linhagens WT, BKO e CD28KO (com background C57BI/6) foram infectados com $2 \times 10^{5}$ formas tripomastigotas i.v. e, em diferentes dias, dois animais de cada grupo foram sacrificados e o soro coletado para avaliação da concentração das proteínas de fase aguda pelo teste ELISA.

Podemos observar que não houve aumento significativo nos níveis de CRP nos animais WT e CD28KO, sendo que os animais BKO apresentaram níveis tão baixos que não foi possível sua quantificação em alguns dos dias avaliados (Fig. 20A).

Por outro lado, os níveis de SAP apresentaram um aumento gradual em todas as linhagens até o dia 13 p.i., sendo observada posteriormente uma queda nos valores obtidos para esta proteína, com os níveis do grupo CD28KO no 18을 dia após a infecção significativamente superior aos do grupo selvagem (Fig. 20B).

Um perfil diferente foi observado quando avaliados os níveis de SAA. Podemos verificar um aumento com valores semelhantes entre as linhagens avaliadas até o $8^{\circ}$ p.i., seguido de uma queda nos animais WT até o dia 18. No entanto, a partir do $35^{\circ}$ dia de infecção observa-se um novo aumento nos níveis séricos desta proteína em todas as linhagens, significativamente maior para os animais BKO no dia 35 quando comparado aos selvagens (Fig. 20C).

Em relação à $\mathrm{MBL}$, os níveis apresentaram uma leve variação ao longo do período avaliado, mas que não se mostrou significativa entre as linhagens estudadas (Fig. 20D). 
Figura 20 - Quantificação de proteínas de fase aguda em animais WT, BKO e CD28KO

A

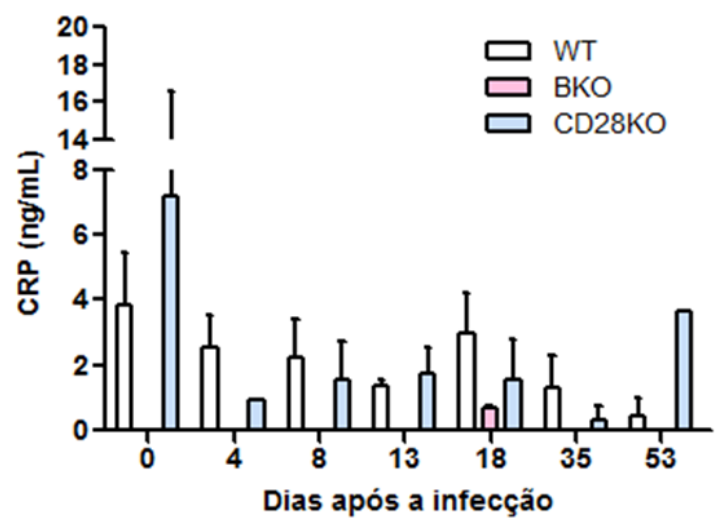

B

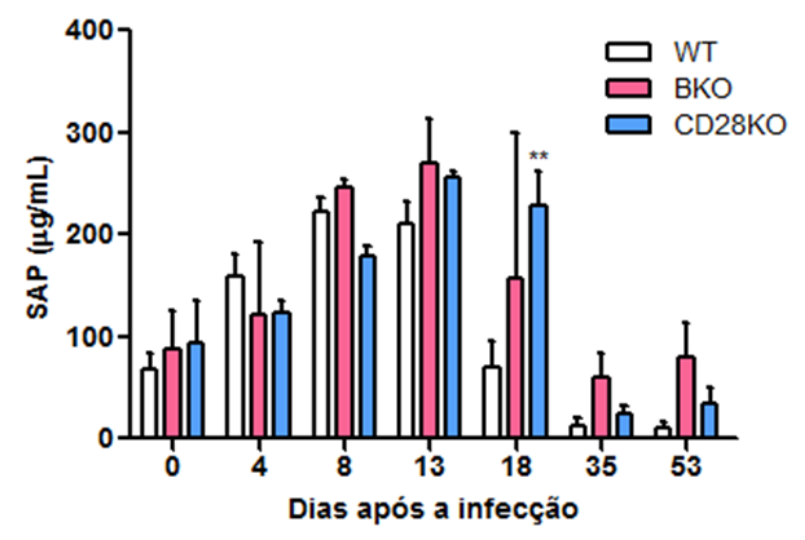

C

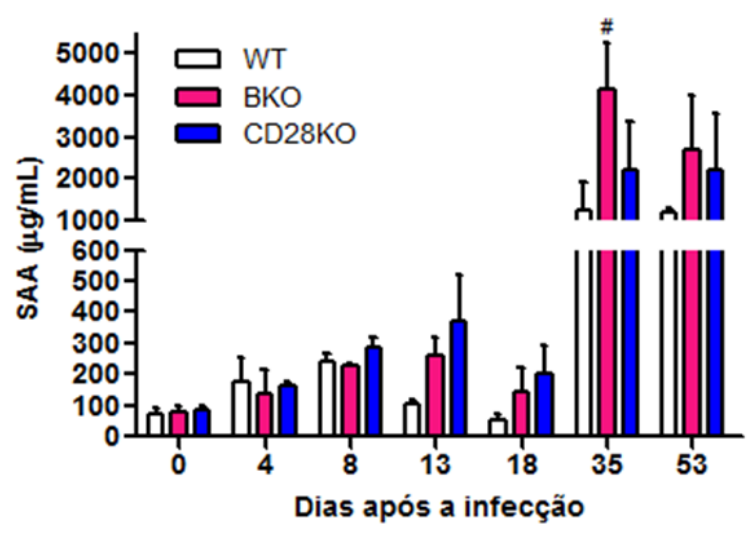

D

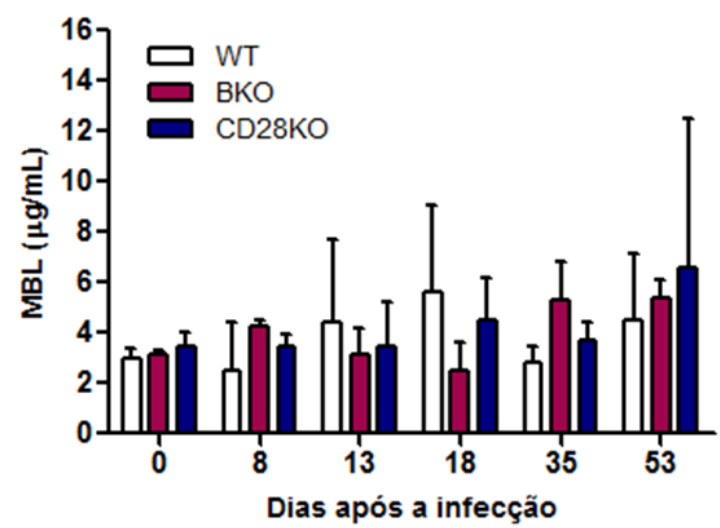

Concentração de proteínas no soro de animais C57BI/6 WT, C57BI/6 BKO e C57BI/6 CD28KO infectados i.v. com $2 \times 10^{5}$ formas tripomastigotas de cultura do clone Sylvio X10/4. (A) Níveis de CRP. (B) Níveis de SAP. (C) Níveis de SAA. (D) Níveis de MBL. Resultados expressos como a Média $\pm S D$ dos valores obtidos de dois experimentos com animais não infectados (dia 0 ) e infectados, avaliandose dois animais de cada grupo por dia. Número total de animais em cada grupo igual a 14 (Two-way ANOVA: ${ }^{* *} p<0,01$ CD28KO em relação ao grupo WT e \#p<0,001 BKO em relação ao grupo WT). 
A pesquisa experimental com cepas de Trypanosoma cruzi de baixa virulência, tais como o clone Sylvio X10/4, permite coletar informações valiosas sobre a interação do $T$. cruzi com o hospedeiro vertebrado que não são possíveis com parasitas de alta virulência.

No presente projeto, o nosso objetivo foi elucidar porque na infecção de camundongos normais pelo parasita do clone Sylvio X10/4 não são visualizados (pelo exame direto no microscópio) formas tripomastigotas circulantes no sangue, mesmo nas primeiras semanas de infecção, ou seja, no período que antecede o desenvolvimento da resposta imune específica (MARINHO et al., 2009).

Em um primeiro bloco de experiências estudamos o perfil da parasitemia, pelo exame direto ao microscópio, em camundongos C57BI/6 WT logo após serem inoculados pela via intravenosa com parasitas do clone Sylvio X10/4, observando-se que 1 hora após a inoculação o número de parasitas circulantes já é muito baixo, não sendo possível identificar parasitas às 24 horas. Utilizando este mesmo protocolo experimental verificamos que formas tripomastigotas do clone Sylvio X10/4 obtidos no $7^{\circ}$ dia de cultura (cultura em células LLCMK2) mostram uma saída mais lenta na primeira hora após serem inoculados do que parasitas obtidos no 9 dia de cultura. Assim, aos 10 minutos da inoculação, os animais injetados com parasitas do $7^{\circ}$ dia em cultura mostram um número de parasitas circulantes duas vezes maiores do que os animais injetados com parasitas mantidos in vitro por 9 dias. Estes resultados sugerem que os parasitas do $7^{\circ}$ dia de cultura exibem maior resistência à remoção da corrente sanguínea, ou, alternativamente, um menor poder de invasão tecidual. Neste contexto, é importante citar os resultados de Pereira et al. (1996) e Rosenberg et al. (1991) indicando que a capacidade invasiva in vitro de parasitas do clone Sylvio X10/4 se correlaciona com a expressão de trans-sialidase, sendo esta mais intensa no parasita recém eclodido que naquele que permaneceu por um tempo no meio extracelular. A partir das experiências comparativas citadas acima adotamos os parasitas do $7^{\circ}$ dia de cultura nos demais experimentos de inoculação com parasitas obtidos in vitro.

É sabido que a manutenção de parasitas em cultura (in vitro) por longos períodos resulta frequentemente em mudanças na infectividade e virulência destes (SILVA et al., 1989). Assim, poderia ser argumentado que a ausência de parasitemia patente em camundongos normais inoculados com parasitas do clone Sylvio X10/4 
poderia ser o resultado da sua propagação in vitro (MARINHO et al., 2009). Entretanto, esta rápida ausência do parasita do clone Sylvio X10/4 no sangue não se mostrou restrita às formas tripomastigotas de cultura de células, uma vez que parasitas do clone Sylvio X10/4 isolados do sangue de animal infectado exibiram curvas de parasitemia similares às observadas com parasitas de cultura.

Diferentemente da infecção por parasitas de baixa virulência como o clone Sylvio X10/4, a infecção de camundongos normais por parasitas da cepa $Y$ (de alta virulência) exibe parasitemia elevada nas duas primeiras semanas da infecção (MARINHO et al., 2004). Equivalente com este perfil, a inoculação intravenosa de parasitas da cepa $Y$ isolados de animal infectado resultou em níveis mais elevados e duradouros de parasitemia patente (até 48 horas pós-inoculação) quando comparados à inoculação de parasitas do clone Sylvio X10/4 de idêntica origem. Entretanto, de forma similar à observada com parasitas do clone Sylvio X10/4, não conseguimos detectar formas tripomastigotas circulantes após 24 horas da inoculação de parasitas da cepa $Y$ procedentes de cultura de células. Tomados em conjunto, os resultados da análise de parasitemia após inoculação i.v. com parasitas do clone Sylvio X10/4 e da cepa $Y$ mostram que a saída de parasitas da cepa $Y$ acontece de forma mais lenta que aquela dos parasitas do clone Sylvio X10/4 somente quando a origem dos parasitas é do sangue de animal infectado.

Uma vez que 24 horas após a inoculação não é mais possível encontrar no sangue formas tripomastigotas circulantes do clone Sylvio X10/4, e sabendo que os parasitas deste clone são considerados miotrópicos (exibem predileção para invadir tecido muscular, seja este cardíaco, liso ou esquelético), avaliamos o destino destes parasitas logo após serem inoculados. Interessantemente, nossos resultados mostram que, 24 horas depois da inoculação, os parasitas do clone Sylvio X10/4 são encontrados preferencialmente no fígado e no baço, sendo que apenas no sangue e nestes dois órgãos encontramos parasitas vivos. Experiências realizadas nas mesmas condições com parasitas da cepa $Y$, que é considerada uma cepa reticulotrópica que infecta principalmente macrófagos (ANDRADE; CARVALHO; FIGUEIRA, 1970), mostrou um perfil de destino muito semelhante ao observado com o clone Sylvio X10/4, com o fígado e o baço sendo os principais órgãos onde os parasitas foram encontrados às 24 horas da sua inoculação. Contudo, na inoculação 
de $T$. cruzi da cepa $Y$, a presença do parasita no baço se revelou mais intensa do que na inoculação de $T$. cruzi clone Sylvio X10/4.

A observação do destino dos parasitas do clone Sylvio X10/4 inoculados é um resultado importante, pois indica que a ausência destes parasitas no sangue no inicio da infecção não pode ser explicada pelo seu tropismo. Mais ainda, levanta a possibilidade destes parasitas serem ativamente removidos.

Conhecendo o perfil de parasitemia e o local onde estariam os parasitas, procuramos então avaliar quais as possíveis moléculas/elementos da resposta imune (inata ou adquirida) que estariam envolvidos nesta rápida ausência do parasita do clone Sylvio X10/4 da corrente sanguínea. Neste contexto, já foi amplamente descrito que os anticorpos específicos participam da resposta protetora contra o T. cruzi (KRETTLI; BRENER, 1976), com papel fundamental na remoção das formas tripomastigotas do sangue (SARDINHA et al., 2010) e tecidos. Nas nossas experiências visamos avaliar se os anticorpos naturais presentes no camundongo não imune poderiam estar envolvidos na remoção inicial do parasita. Para isso comparamos as curvas de parasitemia de parasitas do clone Sylvio X10/4 de cultura inoculados em camundongos C57BI/6 WT e C57BI/6 SCID, estes últimos desprovidos de linfócitos T e B (BOSMA; CARROLL, 1991), portanto, carentes de anticorpos naturais. Os resultados sugerem que os anticorpos naturais não têm um papel muito importante na saída do parasita da corrente sanguínea. No entanto, os animais C57BI/6 SCID possivelmente apresentam algum mecanismo de controle destes parasitas no sangue, uma vez que a positividade das culturas em meio LIT com sangue obtida às $72 \mathrm{~h}$ da inoculação foi inferior nos animais deficientes.

O sistema complemento, juntamente com os fagócitos e células NK, faz parte da primeira barreira enfrentada pelo $T$. cruzi, a imunidade inata. Uma vez que estudos já mostraram que o sistema complemento pode reconhecer e eliminar formas tripomastigotas metacíclicas do parasita limitando seu sucesso na invasão de células do hospedeiro (CESTARI; RAMIREZ, 2010), avaliamos a parasitemia pelo parasita do clone Sylvio X10/4 em animais com o sistema complemento temporariamente eliminado devido o tratamento com Cobra Venom Factor (CVF). Neste estudo analisamos a saída de parasitas provenientes de cultura in vitro e de parasitas isolados de animais imunodeficientes (para anticorpos). No primeiro caso (inoculação de formas tripomastigotas provenientes de cultura celular) não 
observamos diferenças significativas na parasitemia dos animais sem complemento e animais controle. Entretanto, quando foram utilizados parasitas provenientes de animais imunodeficientes, nos primeiros minutos da infecção foi observada uma quantidade maior de formas tripomastigotas circulantes nos animais desprovidos de complemento. Assim, em uma infecção com parasitas isolados do sangue de animais imunodeficientes, o sistema complemento parece contribuir para a remoção do parasita nos primeiros minutos da infecção.

Em um segundo bloco de experiências procuramos avaliar alguns dos elementos que poderiam estar envolvidos na ausência de formas tripomastigotas do clone Sylvio X10/4 no sangue em fases posteriores da infecção. Assim, uma citocina de extrema importância no controle do Trypanosoma cruzi é o IFN- $\gamma$, devido a sua ação sobre a atividade microbicida de macrófagos, mudança de classe de anticorpos e outras ações sobre diversos elementos da resposta imunológica (SCHRODER et al., 2004). Em trabalho anterior do nosso laboratório, Marinho e colaboradores (2007) mostraram que o IFN- $\gamma$ é o principal elemento envolvido no controle do clone Sylvio X10/4. Mais recentemente, Rodrigues e colaboradores (2012), utilizando camundongos inoculados com a cepa $G$, uma cepa que também é considerada de baixa virulência e pertence ao DTU T. cruzi I como o clone Sylvio X10/4, mostraram que a produção de IFN- $\gamma$ é de extrema importância para controlar a infecção por este parasita. Diferentemente da infecção de camundongos normais, na infecção de camundongos deficientes em IFN- $\gamma$ (IFN- $\gamma \mathrm{KO}$ ) por parasitas do clone Sylvio X10/4 detectamos parasitas circulantes, mas curiosamente de forma descontínua. Inicialmente postulamos que esta parasitemia patente poderia ser devida à ausência ou deficiência nestes animais de moléculas envolvidas na remoção dos parasitas, moléculas que dependeriam do IFN- $\gamma$ para uma produção otimizada. No entanto, consideramos também a possibilidade da parasitemia patente resultar como consequência da altíssima carga parasitária destes animais, que ultrapassaria a capacidade de remoção do parasita pelas células ou fatores solúveis do sistema imune. Desta forma, buscamos avaliar quais elementos poderiam estar ausentes ou em menor quantidade no animal C57BI/6 IFN- $\gamma \mathrm{KO}$ infectado, contribuindo à parasitemia intermitente. 
Deixando de lado os receptores de membrana, a lista de moléculas solúveis que podem estar envolvidas na remoção do parasita do clone Sylvio X10/4 é muito extensa. Esta inclui pentraxinas (CRP, SAP, PTX3) (SHISHIDO et al., 2012), apoliproteínas (SAA) (MALLE; STEINMETZ; RAYNES, 1993), colectinas (MBL, surfactantes) e ficolinas (HOLMSKOV; THIEL; JENSENIUS, 2003), grande parte delas descritas como fatores com capacidade de ligar microorganismos e promover sua eliminação. Durante a fase aguda de muitas infecções, as denominadas proteínas de fase aguda apresentam níveis aumentados (WHITEHEAD et al., 1990), e como algumas possuem papel opsonizante e ativador de complemento, estudamos de inicio se a produção de quatro destas proteínas estariam relacionadas ao perfil intermitente de parasitemia dos animais C57BI/6 IFN- $\gamma \mathrm{KO}$.

A proteína $C$ reativa manteve-se em um nível baixo e apenas apresentou aumento significativo no decorrer da infecção pelo $T$. cruzi nos animais IFN- $\gamma \mathrm{KO}$ (no dia 13 p.i.), resultado esperado uma vez que este fator, apesar de ser a proteína de fase aguda mais aumentada nas infecções em humanos, não sofre grandes aumentos na infecção de camundongos (ECKERSALL, 2000). Assim como em estudos anteriores que já tinham apontado que a indução de SAP faz parte da resposta humoral murina à infecção com T. cruzi (SCHARFSTEIN; BARCINSKI; LEON, 1982; CRAY; ZAIAS; ALTMAN, 2009), nossas experiências mostraram que os níveis de SAP no plasma de camundongos C57BI/6 WT aumentaram até o 8o dia de infecção e começaram a decrescer a partir do $13^{\circ}$ dia. Em relação à SAA, os níveis no plasma de camundongos WT infectados mostraram uma cinética similar aos de SAP até o dia 18 após a infecção. Já nos camundongos IFN- $\gamma \mathrm{KO}$, as proteínas SAP e SAA aumentaram significativamente a partir do $13^{\circ}$ dia p.i. (em comparação ao grupo WT). Agindo em dois braços da resposta imune inata (ARAl; TABONA; SUMMERFIELD, 1993), já foi descrito que a interação da MBL com microrganismos poderia resultar tanto na remoção destes por células com receptores para colectinas, quanto na ativação da cascata do complemento (KAHN, 1996). Nos nossos estudos, a MBL não apresentou variação nos níveis séricos nos animais normais, enquanto que no grupo imunodeficiente observamos um aumento significativo a partir do dia 13 de infecção. Desta forma, os nossos resultados permitem concluir que a parasitemia patente intermitente encontrada nos camundongos IFN- $\gamma \mathrm{KO}$ infectados por parasitas do clone Sylvio X10/4 não pode ser 
atribuída a déficits na produção de proteínas de fase aguda. Estudos mais aprofundados são necessários para verificar se SAP, SAA e MBL, assim como outras moléculas solúveis, participam da remoção ativa do parasita do clone Sylvio X10/4.

Em continuidade aos nossos estudos sobre a ação dos anticorpos no controle do parasita buscamos avaliar também a importância destas moléculas ao longo da infecção. Já foi descrito que a transferência passiva de anticorpos protege da fase aguda da infecção por formas tripomastigotas da cepa $Y$ e, somado a isso, há uma queda na infectividade dos parasitas tratados com soro imune (KRETTLI; BRENER, 1976). Além disso, anticorpos parasita-específicos agem na opsonização e neutralização do parasita. Quando avaliamos a infecção por parasitas do clone Sylvio X10/4 em animais C57BI/6 BKO (que carecem de anticorpos em função da deficiência de linfócitos $B$ maduros) observamos uma alta suscetibilidade, uma vez que todos os animais vieram a falecer. Estes resultados estão de acordo com o descrito por Kumar e Tarleton (1998) e indicam que, mesmo na infecção por um parasita de baixa virulência como o clone Sylvio X10/4, os anticorpos específicos são importantes como elemento de controle.

Considerando o perfil Th1 da resposta ao T. cruzi, a presença de um padrão de resposta de anticorpos IgG é esperado, principalmente IgG2a; contudo, animais que não possuem a molécula co-estimuladora CD28 (CD28KO) não apresentam a troca de isotipo de anticorpos e, assim, só apresentam anticorpos específicos da classe IgM (MARINHO et al., 2007). Estudos anteriores do nosso laboratório apontam que camundongos C57BI/6 CD28KO infectados com formas tripomastigotas do clone Sylvio X10/4 controlam a infecção (MARINHO et al., 2009). Nossos resultados, comparando a mortalidade de camundongos C57BI/6 CD28KO e C57BI/6 BKO infectados, apontam apenas a suscetibilidade dos animais carentes de ambas às classes de anticorpos (dentro do período analisado). Desta forma, podemos concluir que os anticorpos naturais não parecem participar no controle do parasita do clone Sylvio X10/4 nos primeiros dias da infecção, no entanto, a médio/longo prazo, na ausência de anticorpos específicos da classe IgG, aqueles da classe IgM parecem essenciais.

Levando-se em consideração os níveis semelhantes da parasitemia subpatente e ausência de parasitemia patente nos animais imunodeficientes C57BI/6 
BKO e C57BI/6 CD28KO, nosso próximo passo foi verificar se os níveis séricos das proteínas de fase aguda nestas duas linhagens exibiriam diferenças que poderiam estar relacionadas às imunodeficiências apresentadas por estes animais. Como já esperado, os níveis de CRP foram baixos nos três grupos avaliados, sendo que nos animais BKO tivemos dificuldades na quantificação. A SAP apresentou aumento nos grupos até $013^{\circ}$ dia seguido de queda durante o período analisado, no entanto, observamos que mesmo com esta diminuição, os níveis nos animais imunodeficientes se mantiveram levemente maiores, principalmente no grupo BKO. $\mathrm{Na}$ avaliação da SAA, não observamos diferenças significativas entre as linhagens imunodeficientes, que mostraram níveis maiores que o grupo selvagem; enquanto que a MBL apresentou apenas pequenas variações ao longo do tempo avaliado. Assim, com estes resultados verificamos que os perfis das proteínas de fase aguda nos grupos BKO e CD28KO são muito semelhantes e não parecem estar relacionados a déficits apresentados por estes animais imunodeficientes.

Em relação ao objetivo central da dissertação, averiguar os elementos responsáveis pela baixa parasitemia na infecção pelo parasita do clone Sylvio X10/4, nossas experiências não chegaram a ser conclusivas, apesar de demonstrarmos a participação parcial do sistema do complemento e a presença elevada do parasita no fígado e baço às 24 horas da sua inoculação pela via intravenosa. Diante disto, experimentos adicionais tornam-se necessários para estimar o papel de outras moléculas, de membrana ou solúveis, e principalmente das proteínas de fase aguda, na saída/remoção do parasita. 
Os resultados obtidos nesse trabalho trazem contribuições para 0 entendimento das possíveis moléculas envolvidas na ausência de parasitemia em camundongos inoculados com o parasita do clone de baixa virulência Sylvio X10/4. Assim, as principais conclusões foram:

- animais inoculados via intravenosa por parasitas do clone de baixa virulência Sylvio X10/4 não apresentam parasitemia patente após 24 horas;

- nas condições experimentais utilizadas na manutenção do T. cruzi in vitro, parasitas isolados do $7^{\circ}$ dia de cultura em células LLCMK2, quando inoculados em camundongos normais, geram níveis superiores de parasitemia que parasitas isolados do $9^{\circ}$ dia de cultura;

- animais C57BI/6 WT infectados com parasitas da cepa de alta virulência $Y$ isolados de cultura de células LLCMK2, da mesma forma que o clone Sylvio X10/4, não apresentam parasitemia patente após 24 horas de infecção, com curvas de parasitemia semelhantes;

- T. cruzi da cepa $\mathrm{Y}$ isolados do sangue de animais imunodeficientes previamente infectados saem mais lentamente da corrente sanguínea;

- a ausência de parasitas do clone Sylvio X10/4 no sangue não pode ser explicada pelo seu miotropismo, uma vez que 24 horas após a inoculação via intravenosa os parasitas foram encontrados preferencialmente no fígado e no baço, indicando a possibilidade dos parasitas serem ativamente removidos;

- anticorpos naturais ( $\lg M$ e $\lg G$ ) não são essenciais para a saída do parasita do clone Sylvio X10/4 nas primeiras horas da infecção;

- o sistema complemento de animais recém-infectados i.v. poderia contribuir na saída das formas tripomastigotas do clone Sylvio X10/4 da corrente 
sanguínea quando os parasitas são isolados do sangue de animais imunodeficientes, mas não quando os parasitas são obtidos de cultura in vitro;

- a ausência da citocina IFN- $\gamma$ leva a uma parasitemia intermitente, a qual não é devida a deficiência de proteínas de fase aguda;

- animais deficientes em linfócitos B são altamente susceptíveis à infecção pelo T. cruzi clone Sylvio X10/4;

- animais C57BI/6 CD28KO são mais resistentes à infecção pelo $T$. cruzi clone Sylvio X10/4 do que os animais C57BI/6 BKO. Este resultado sugere que, a médio/longo prazo, o anticorpo específico IgM tem efeito protetor na infecção por parasitas do clone Sylvio X10/4;

- apesar da ausência de parasitemia patente e parasitemias subpatentes muito parecidas nos animais C57BI/6 BKO e C57BI/6 CD28KO, os perfis semelhantes encontrados na produção das proteínas de fase aguda não parecem estar relacionados às imunodeficiências destas duas linhagens. 


\section{REFERÊNCIAS}




\section{REFERÊNCIAS*}

ABBAS, A. K.; LICHTMAN, A. H.; PILLAI, S. Imunidade Inata. In: Imunologia celular e molecular. 7. ed. Rio de Janeiro: Elsevier, 2011. p. 55-88.

ANDRADE, S. G.; CARVALHO, M. L.; FIGUEIRA, R. M. Caracterização morfobiológica e histopatológica de diferentes cepas do Trypanosoma cruzi. Gaz. Med. Bahia, v. 70, p. 32-42, 1970.

ANIS, R. J.; RASSI, A.; MARIN-NETO, J. A. Chagas disease. Lancet, v. 375, n. 9723, p. 1388-1402, 2010.

ANTÚNEZ, M. I.; CARDONI, R. L. IL-12 and IFN- $\gamma$ production, and NK cell activity, in acute and chronic experimental Trypanosoma cruzi infections. Immunol. Lett., v. 71, n. 2, p. 103-109, 2000.

ARAI, T.; TABONA, P.; SUMMERFIELD, J. A. Human mannose-binding protein gene is regulated by interleukins, dexamethasone and heat shock. QJM: Int. J. Med., v. 86 , n. 9, p. 575-582, 1993.

BIOLO, A.; RIBEIRO, A. L.; CLAUSSEL, N. Chagas cardiomyopathy - where do we stand after a hundred years? Prog. Cardiovasc. Dis., v. 52, n. 4, p. 300-316, 2010.

BOSMA, M. J.; CARROLL, A. M. The SCID mouse mutant: definition, characterization, and potential uses. Annu. Rev. Immunol., v. 9, p. 323-350, 1991.

BRATTACHARYYA, T. et al. Analysis of molecular diversity of the Trypanosoma cruzi trypomastigote small surface antigen reveals novel epitopes, evidence of positive selection and potential implications for lineage-specific serology. Int. J. Parasitol., v. 40, n. 8, p. 921-928, 2010.

BRENER, Z. Biology of trypanosome cruzi. Annu. Rev. Microbiol., v. 27, p. 347382, 1973.

BRODSKYN, C. I. et al. IgG subclasses responsible for immune clearance in mice infected with Trypanosoma cruzi. Immunol. Cell. Biol., v. 67, n. 6, p. 343-348, 1989.

BUDZKO, D. B.; PIZZIMENTI, M. C.; KIERSZENBAUM, F. Effects of complement depletion in experimental chagas disease: immune lysis of virulent blood forms of Trypanosoma cruzi. Infect. Immun., v. 11, n. 1, p. 86-91, 1975.

\footnotetext{
*De acordo com:

ASSOCIAÇÃO BRASILEIRA DE NORMAS TÉCNICAS. NBR 6023: informação e documentação: referências: elaboração. Rio de Janeiro, 2002.
} 
CESTARI, I.; RAMIREZ, M. I. Inefficient complement system clearance of Trypanosoma cruzi metacyclic trypomastigotes enables resistant strains to invade eukaryotic cells. Plos One, v. 5, n. 3, p. 1-11, 2010.

CONTRERAS, V. T. et al. Trypanosoma cruzi: Metacyclogenesis in vitro: I. changes in the properties of metacyclic trypomastigotes maintained in the laboratory by different methods. Mem. Inst. Oswaldo Cruz, v. 89, n. 2, p. 253-259, 1994.

CRAY, C.; ZAIAS, J; ALTMAN, N. H. Acute phase response in animals: a review. Comp. Med., v. 59, n. 6, p. 517-526, 2009.

CUNHA-NETO, E. et al. Autoimmunity in Chagas disease cardiopathy: biological relevance of a cardiac myosin-specific epitope crossreactive to an immunodominant Trypanosoma cruzi antigen. Proc. Natl. Acad. Sci., v. 92, n. 8, p. 3541-3545, 1995.

ECKERSALL, P. D. Recent advances and future prospects for the use of acute phase proteins as makers of disease in animals. Revue Méd. Vét., v. 151, n. 7, p. 577-584, 2000.

FUNDAÇÃO OSWALDO CRUZ. Doença de Chagas. 2012. Disponível em: <http://www.fiocruz.br/chagas/cgi/cgilua.exe/sys/start.htm?tpl=home>. Acesso em: 9 nov. 2012.

GABOLDE, M. et al. Association of variant alleles of mannose binding lectin with severity of pulmonary disease in cystic fibrosis: cohort study. Brit. M. J., v. 319, p. 1166-1167, 1999.

GOLDEN, J. M.; TARLETON, R. L. Trypanosoma cruzi: cytokine effects on macrophage trypanocidal activity. Exp. Parasitol., v. 72, n. 4, p. 391-402, 1991.

HANSEN, S. et al. Purification and characterization of two mannan-binding lectins from mouse serum. J. Immunol., v. 164, n. 5, p. 2610-2618, 2000.

HOTEZ, P. J. et al. Rescuing the bottom billion through control of neglected tropical diseases. Lancet, v. 373, n. 9674, p. 1570-1575, 2009.

HOLMSKOV, U.; THIEL, S.; JENSENIUS, J. C. Collectins and ficolins: humoral lectins of innate immune defense. Annu. Rev. Immunol., v. 21, p. 547-578, 2003.

JOSHI, T.; BUTCHAR, J. P.; TRIDANDAPANI, S. Fcgamma receptor signaling in phagocytes. Int. J. Hematol., v. 84, n. 3, p. 210-216, 2006. 
JUNQUEIRA, C. et al. The endless race between Trypanosoma cruzi and host immunity: lessons for and beyond Chagas disease. Exp. Rev. Mol. Med., v. 12, n. 29, p. 1-23, 2010.

$\mathrm{KAHN}$, S. et al. Trypanosoma cruzi amastigote adhesion to macrophages is facilitated by the mannose receptor. J. Exp. Med., v. 182, n. 5, p. 1243-1258, 1995.

KAYAMA, H.; TAKEDA, K. The innate immune response to Trypanosoma cruzi infection. Microb. Infect., v. 12, n. 7, p. 511-517, 2010.

KIPNIS, T. L. et al. Comparison of the C-mediating killing activity and C-activating properties of mouse monoclonal and polyclonal antibodies against Trypanosoma cruzi. Mediators Inflamm., v. 1, p. 309-312, 1992.

KITAMURA, D. et al. A B cell-deficient mouse by targeted disruption of the membrane exon of the immunoglobulin mu chain gene. Nature, v. 350, n. 6317, p. 423-426, 1991.

KRETTLI, A. U.; BRENER, Z. Protective effects of specific antibodies in Trypanosoma cruzi infections. J. Immunol., v. 116, n. 3, p. 755-760, 1976.

KUMAR, S.; TARLETON, R. L. The relative contribution of antibody production and $\mathrm{CD}^{+} \mathrm{T}$ cell function to immune control of Trypanosoma cruzi. Paras. Immunol., v. 20, n. 5, p. 207-216, 1998.

LESCURE, F. X. et al. Chagas disease: changes in knowledge and management. Lancet Infect. Dis., v. 10, n. 8, p. 556-570, 2010.

LOPES, E. S. G.; PRADO JÚNIOR, J. C. A influência da cepa Y de Trypanosoma cruzi no coração em ratos wistar machos submetidos ao processo de adrenalectomia. Biodiversidade, v. 6, n. 1, p. 62-76, 2007.

MACHADO, C. M. et al. Epidemiology of neglected tropical diseases in transplant recipients. Review of the literature and experience of a Brazilian HSCT center. Rev. Inst. Med. Trop. S. Paulo, v. 51, n. 6, p. 309-324, 2009.

MALLE, E.; STEINMETZ, A.; RAYNES, J. G. Serum amyloid A (SAA): an acute phase protein and apoliprotein. Atheroscler. Suppl., v. 102, n. 2, p. 131-146, 1993.

MARINHO, C. R. F. et al. Influence of acute phase parasite load on pathology, parasitism, and activation of the immune system at the late chronic phase of Chagas disease. Infect. Immun., v. 67, n. 1, p. 308-318, 1999. 
MARINHO, C. R. F. et al. Pathology affects different organs in two mouse strains chronically infected by a Trypanosoma cruzi clone: a model for genetic studies in Chagas' disease. Infect. Immun., v. 72, n. 4, p. 2350-2357, 2004.

MARINHO, C. R. F. et al. IFN- $\gamma$ but not nitric oxide or specific IgG, is essential for the in vivo control of low-virulence Sylvio X10/4 Trypanosoma. cruzi parasites. Scand. J. Immunol., v. 66, n. 2-3, p. 297-308, 2007.

MARINHO, C. R. F. et al. Infection by the Sylvio X10/4 clone of Trypanosoma cruzi: relevance of a low-virulence model of Chagas' disease. Microb. Infect., v. 11, n. 13, p. 1037-1045, 2009.

MARTINS, G. A. et al. CD28 is required for $T$ cell activation and IFN-gamma production by CD4+ and CD8+ T cells in response to Trypanosoma cruzi infection. Microb. Infect., v. 6, n. 13, p. 1133-1144, 2004.

MATSUDA, N. M; MILLER, S. M.; EVORA, P. R. B. The chronic gastrointestinal manifestations of Chagas disease. Clinics, v. 64, n. 12, p. 1219-1224, 2009.

MELO, R. C.; BRENER, Z. Tissue tropismo $f$ different Trypanosoma cruzi strains. J. Parasitol., v. 64, n. 3, p. 475-482, 1978.

MILES, M. A. Cloning Trypanosoma cruzi. Trans. R. Soc. Trop. Med. Hyg., v. 68, n. 3, p. 256, 1974.

MOTA, I.; UMEKITA, L. F. The effect of C3 depletion on the clearance of Trypanosoma cruzi induced by IgG antibodies. Immunol. Lett., v. 21, n. 3, p. 223225, 1989.

OGDEN, C. A. et al. C1q and mannose binding lectin engagement of cell surface calreticulin and CD91 initiates macropinocytosis and uptake of apoptotic cells. J. Exp. Med., v. 194, n. 6, p. 781-795, 2001.

PEREIRA, M. E. et al. Invasive phenotype of Trypanosoma cruzi restricted to a population expressing trans-sialidase. Infect. Immun., v. 64, n. 9, p. 3884-3892, 1996.

POSTAN, M.; DVORAK, J. A.; McDANIEL, J. P. Studies of Trypanosoma cruzi clones in inbred mice. I. A comparison of the course of infection of $\mathrm{C} 3 \mathrm{H} / \mathrm{HEN}^{-}$mice with two clones isolated from a common source. Am. J. Trop. Med. Hyg., v. 32, n. 3, p. 497-506, 1983. 
RODRIGUES, A. A. et al. IFN- $\gamma$ plays a unique role in protection against low virulent Trypanosoma cruzi strain. Plos. Negl. Trop. Dis., v. 6, n. 4, p. 1-9, 2012.

ROSENBERG, A. I. et al. Differential expression on Trypanosoma cruzi neuraminidase in intra- and extracellular trypomastigotes. Infect. Immun., v. 59, n. 1, p. 464-466, 1991.

ROTTENBERG, M. et al. Role of T Helper/Inducer cells as well as Natural Killer Cells in resistance to Trypanosoma cruzi infection. Scand. J. Immunol., v. 28, n. 5, p. 573$582,1988$.

SARDINHA, L. R. et al. The liver plays a major role in clearance and destruction of blood trypomastigotes in Trypanosoma cruzi chronically infected mice. Plos. Negl. Trop. Dis., v. 4, n. 1, p. 1-9, 2010.

SCHARFSTEIN, J.; BARCINSKI, M. A.; LEON, L. L. Induction of the acute-phase protein serum amyloid $P$ in experimental Chagas' disease. Infect. Immun., v. 35, n. 1, p. 46-51, 1982.

SCHRODER, K. et al. Interferon- $\gamma$ : an overview of signals, mechanisms and functions. J. Leukoc. Biol., v. 75, n. 2, p. 163-189, 2004.

SHISHIDO, S. N. et al. Humoral innate immune response and disease. Clin. Immunol., v. 144, n. 2, p. 142-158, 2012.

SILVA, A. M. M. et al. Differences in the antigenic profile of bloodstream and cell culture derived trypomastigotes of Trypanosoma cruzi. Rev. Inst. Med. Trop. São Paulo, v. 31, n. 3, p. 146-150, 1989.

SILVA, G. K. et al. Cutting edge: nucleotide-binding oligomerization domain 1dependent resposnses account for murine resistance against Trypanosoma cruzi infection. J. Immunol., v. 184, n. 3, p. 1148-1152, 2010.

SILVEIRA, F. et al. Nono caso autóctone de doença de Chagas registrado no estado do Pará, Brasil. Hileia Med., v. 1, p. 61-62, 1979.

STADNYK, A. W.; GAULDIE, J. The acute phase protein response during parasitic infection. Trends. Immunol., v. 12, n. 3, p. 7-12, 1991.

STEEL, D. M.; WHITEHEAD, A. S. The major acute phase reactants: C-reactive protein, serum amyloid $P$ component and serum amyloid A protein. Immunol. Today, v. 15, n. 2, p. 81-88, 1994. 
TAKEHARA, $\mathrm{H}$. A. et al. Trypanosome cruzi: role of different antibody classes in protection against infection in the mouse. Exp. Parasitol., v. 52, n. 1, p. 137-146, 1981.

TAMBOURGI, D. V. et al. Detection of Trypanosoma-decay accelerating factor antibodies in mice and humans infected with Trypanosoma cruzi. Am. J. Trop. Med. Hyg., v. 52, n. 6, p. 516-520, 1995.

UMEKITA, L. F.; TAKEHARA, H. A.; MOTA, I. Role of the antibody Fc in the immune clearance of Trypanosoma cruzi. Immunol. Lett., v. 17, n. 1, p. 85-89, 1988.

UMEKITA, L. F.; RAMOS, D. P.; MOTA, I. Clearance-inducing antibodies are responsible for protection against the acute phase of Trypanosoma cruzi infection in mice. Braz. J. Med. Biol. Res., v. 30, n. 10, p. 1191-1197, 1997.

URIELI-SHOVAL, S.; LINKE, R. P.; MATZNER, Y. Expression and function of serum amyloid $A$, a major acute-phase protein, in normal and disease states. Curr. Opin. Hematol., v. 7, n. 1, p. 64-69, 2000.

WHITEHEAD, A. S. et al. Mouse C-reactive protein. Generation of cDNA clones, structural analysis, and induction of mRNA during inflammation. Biochem. J., v. 266, n. 1, p. 283-290, 1990.

WORLD HEALTH ORGANIZATION. Chagas disease (American trypanosomiasis). Aug 2012. Disponível em: <http://www.who.int/mediacentre/factsheets/fs340/en/>. Acesso em: 5 abr. 2012.

ZINGALES, B. et al. A new consensus for Trypanosoma cruzi intraspecific nomenclature: second revision meeting recommends Tcl to TcVI. Mem. Inst. Oswaldo Cruz, v. 104, n. 7, p. 1051-1054, 2009. 